\title{
Povos indígenas, o Estado brasileiro e a futela contemporônea: genealogia da luta pelos territórios e pelo meio ambiente a partir das leis
}

Indigenous peoples, the brazilian State and the contemporary tutela: genealogy of the fight for the territories and for the environment starting from the laws

Resumo: A história de luta pelo reconhecimento de direitos territoriais dos povos indígenas e direitos ao meio ambiente 'ecologicamente equilibrado' - expressão que passa a ser inserida a partir da Carta Magna/88 (Art. 225, caput) - revela que a lei exerce um poder sobre ambos os temas tão antigo quanto essa luta. A genealogia decorre de uma inquietante questão: quais os primórdios de reconhecimentos legais que incidem a povos indígenas, seus territórios e o meio ambiente? Essa busca genealógica parte dos séculos XVI ao XIX mos-

1 JULIÃO, Cristiane G., sou indígena do povo Pankararu, membro da Articulação dos Povos e Organizações Indígenas do Nordeste, Minas Gerais e Espírito Santo (APOINME) e da Articulação dos Povos Indígenas do Brasil (APIB), atualmente, doutoranda em Antropologia Social pelo Museu Nacional, Universidade Federal do Rio de Janeiro (MN/ UFRJ). Texto extraído de minha dissertação de mestrado defendida em 19 de fevereiro de 2018, pelo Programa de Pós-Graduação em Antropologia Social - Museu Nacional Universidade Federal do Rio de Janeiro. 
trando como a lei nos foi imposta, de modo tutelar e com negação de direitos. Somente a partir de meados do século $X X$ vem a se reconhecer direitos fundamentais, territoriais e ambientais confirmados em 34 instrumentos internacionais ratificados pelo Brasil e na Constituição Federal/1988. Este artigo busca mostrar também, como se configura o que chamei de "personalidade política" do Brasil calçada num conjunto de ideias preconceituosas e de esbulho, a partir do contato entre povos indígenas e colonizadores portugueses, depois com o Estado Nacional Brasileiro, ao longo dos períodos imperial e republicano. A luta se revela contínua e sem muita segurança legal dada as constantes violações desses direitos e ainda por ameaças de proposituras anti-indígenas pelos três poderes e pela tutela contemporânea.

Palavras chaves: Povos indígenas, Estado brasileiro, meio ambiente, direitos e legislação.

Abstract: The history of the struggle for the recognition of indigenous peoples' rights and the rights to the environment 'ecologically balanced' an expression that begins to be inserted after the Magna Carta / 88 (Article 225 , caput) - reveals that the law exercises a power on both themes as old as this fight. The genealogy stems from a disturbing question: what are the beginnings of legal recognition that affect indigenous peoples, their territories and the environment? This genealogical search dates from the 16th to the 19th centuries showing how the law was imposed on us, in a tutelary way and with denial of rights. Only from the middle of the twentieth century has the recognition of fundamental, territorial and environmental rights confirmed in 34 international instruments ratified by Brazil and in the Federal Constitution / 1988. This article also seeks to show how what I called the "political personality" of Brazil in a set of prejudiced and sneaky ideas was defined, starting from the contact between indigenous peoples and Portuguese colonizers, then with the Brazilian National State, along the imperial and republican periods. The struggle proves to be continuous and without much legal certainty given the constant violations of these rights and also by threats of anti-indigenous proposals by the three powers and by the contemporary tutela. 
Keywords: Indigenous peoples, Brazilian state, environment, rights and legislation.

\section{INTRODUÇÃO}

De modo algum é exagero literário falar da genealogia da luta pelo território e implicitamente pelo meio ambiente, uma vez que pensar terras indígenas não significa apenas um espaço físico, mas toda biodiversidade da fauna e da flora que fazem parte dos modos de vida de cada povo indígena, independentemente de localização geográfica. Como também não é exagero a busca de informações que esclareçam a situação atual dos povos indígenas no Brasil, onde grande parte se encontra sem seus territórios pela falta de regularização destes. Quanto à Lei, surge como instrumento de coerção, dominação e poder imposto aos indígenas, instrumento este tão antigo quanto os personagens dessa contenda histórica.

Numa genealogia romântica e simplória não diria "no princípio era trevas...", para esse contexto, a gênese poderia começar com Era uma vez... tripulantes de treze caravelas que ao navegarem pelo Atlântico por longo período (não importa o quanto), enfim gritaram: "Terra à vista!", e se depararam com criaturas exóticas, sem fé, sem lei e sem $\mathrm{rei}^{2}$. Esses habitantes teriam alguma serventia: a de serem escravizados, catequizados, amansados e terem seus territórios espoliados, suas florestas demasiadamente exploradas e ainda serem rotulados de selvagens. Este é um resumo em linhas gerais sobre a origem da contenda entre índios e brancos para narrar os acontecimentos históricos da colonização ${ }^{3}$.

Nesse trabalho, procurei trazer temas importantes para os povos indígenas que partem desse pressuposto, com destaque para a tutela, que se consolidou como mecanismo de controle social "mais assertivo" do Estado brasileiro para com os povos indígenas a partir de uma

2 Pacheco de Oliveira \& Freire, 2006, p. 27 [Gabriel Soares de Souza, 1971].

3 Ibidem. 
"personalidade política" dúbia - sem querer pretender com isso personificar o Estado brasileiro, o que é impossível, minha colocação está na compreensão do conjunto de ações características de comportamentos quando o público direto e singular são os povos indígenas.

A organização geológica/temporal para esse artigo foi estruturada em três intervalos com espaçamentos distintos, dada à relevância narrativa desses/nesses períodos. Sintetizando, no primeiro momento procuro trazer dados circunstanciais que conformam uma contextualização dos primeiros contatos (índios e brancos) ao momento atual no tocante a poder, legislação, política e tutela contemporânea; no segundo momento procuro identificar o longo processo de percepção e inserção de indígenas e do meio ambiente ao ordenamento jurídico brasileiro e ao final uma "celeridade temporal" a partir dos anos de 1970; no terceiro momento e não menos importante, uma apresentação a partir do contato entre povos indígenas e colonizadores portugueses, depois com o Estado Nacional Brasileiro, ao longo dos períodos imperial e republicano, reputa o que chamei de "personalidade política" do Brasil calçada num conjunto de ideias preconceituosas e de esbulho.

O que fomenta esse trabalho para além de uma genealogia, não é o estudo sobre o trâmite processual e de sua rotina burocrática com prazos, mandados, audiências, pareceres, vistas, decisões ou sentenças. O que quero é (me) esclarecer sobre o que levou a que certos direitos para os povos indígenas fossem estabelecidos e não fossem cumpridos, de modo a colaborar para que nós indígenas entendamos melhor o que se passa entre a lei e a política, e nos tornemos mais preparados de nos defender independente da argumentação jurídica. Quero contribuir para que percebamos que legislar não é fazer cumprir a lei, ou punir de acordo com ela, para isso sendo fundamental, do meu ponto de vista, entender que se tudo é Estado (que legisla, que executa e que julga), esse conceito não recobre um ente único, coeso e homogêneo.

Penso, pois, que, na luta pelo território e o meio ambiente é preciso considerar duas iminentes hipóteses: a heterogeneidade dos grupos políticos que ocupam a administração pública direta, que se fazem representar no Legislativo e que compõem o Judiciário, bem como a participação de agentes "externos" a essas instâncias de adminis- 
tração e governança que incitam e acirram mais ainda essa luta; e a possibilidade de que essa luta redunde no campo da disputa jurídica, em Tribunais de Justiça que não são isentos como a seguinte ficção que os brancos nos vendem.

A importância é trazer outro olhar sobre o Estado brasileiro e a relação com um peculiar público - os povos indígenas, afinal nós somos a outra parte dessa relação desde o "achamento"4 do Brasil, um reexame dessa relação de muitas emoções.

\section{CONFORMANDO A GENEALOGIA DAS LUTAS E DAS LEIS}

Aludi esse trabalho à genealogia porque quis buscar os primórdios de reconhecimentos legais que incidem em povos indígenas, seus territórios e o meio ambiente com o objetivo de chamar atenção para a lei enquanto categoria de poder e os efeitos do seu mantra "lei é lei". Assim, a melhor forma de começar essa investigação é ampliar esse conto simplório descrito na introdução a partir da história que não foi contada ou foi reformulada em detrimento dos povos indígenas e do meio ambiente, afinal essa luta foi regulamentada em várias Cartas Régias, Regimentos, Decretos, Alvarás, Provisões, Leis, Marcos Internacionais assinados pelo Brasil, conforme se apresentam no material anexo deste artigo.

De fato, essa seria a vertente histórica que deflagraria a genealogia das lutas e das leis, pois é uma investigação que por si só trará muito material. Mas, para este trabalho, a origem não está exatamente no marco legal, e sim nas relações que deram origem a legalização de ações que se tornaram legítimas e inerentes ao e/feito legal a depender dos interesses envolvidos, ao tempo que descontruía legalmente a legitimidade dos povos originários, de tal modo que até os idos atuais, nós indígenas somos orientados a acreditar que a lei dispõe

4 Pacheco de Oliveira (2016:48) revela que na carta de Caminha, o mesmo não falava em descobrimento, e sim em achamento. Este era o termo empregado na documentação da época, que depois foi intitulado de descobrimento. 
de uma supremacia inquestionável, de modo que pleitear um direito é igualmente apelar para que esse direito reconhecido como lei seja aplicado. Há quem possa dizer que esse pleito não é demanda só de indígenas, vários coletivos sociais acionam esse discurso de acordo com suas especificidades. Todavia, o olhar de inserção como sujeitos sociais e de direitos são distintos como veremos abaixo na contextualização de contendas seculares da relação dominantes-dominados-espaços, manipuladas pelo argumento da lei e da tutela cada vez mais contemporânea.

Em outras palavras, para os povos indígenas é um cruel sofrimento moral e físico reivindicar por justiça ao Estado brasileiro disputando argumentos entre quem tem o direito em detrimento do outro. É um campo de disputa. São espaços de luta no aspecto intelectual, porque demanda ter apropriação não exatamente da aplicação da lei, mas entender para qual objetivo ela existe. É por isso que a Antropologia tem um rico papel nessa discussão: na direção oposta aos cursos e livros de direito, pode contribuir para a construção de outra-história sobre momentos na formação do Estado brasileiro, sem deixar de olhar para o Estado como o responsável pela não resolução das lutas dos povos indígenas,

procurando esmiuçar os sentidos das práticas e dos saberes, indagando se a singularidade da situação etnográfica pesquisada tem algo a nos dizer sobre o universo de possibilidades, em favor de uma interpretação não etnocêntrica, e, portanto, não arbitrária (LINS RIBEIRO, 2012, pp. 11-12). ${ }^{5}$

Fomos ou somos levados a crer que "a lei é para todos", porque se acredita que para toda formação de um Estado (mono)nacional é necessário normatizar e padronizar direitos e deveres, para todos aqueles que compõem essa construção social identificada a um espaço geográfico definido. A questão é que, para os povos indígenas

5 Para mais informações, ver Cardoso de Oliveira; Grossi. In: Antropologia e direito: temas antropológicos para estudos jurídicos. Antonio Carlos de Souza Lima (Coord.). Brasília/ Rio de Janeiro/Blumenau: Associação Brasileira de Antropologia/LACED/Nova Letra, 2012. 
e o meio ambiente, esse conjunto de normas teve processos, motivos e tempos distintos. Por isso, antes de reivindicar esses direitos, soa de suma importância conhecer a cronologia desses regimentos, porque a luta pelo território e o meio ambiente é tão antiga quanto suas legislações.

O Brasil, enquanto Estado nacional independente, "herdou" diversos elementos da colonização portuguesa, inclusive uma forma de tratar os povos indígenas. O primeiro passo está na busca de subsídios históricos, visitando situações de contato com os povos indígenas e as formas de exploração econômica sobre bens e recursos naturais, bem como referências sobre algumas fases na formação espacial do Estado brasileiro que conformaram o modo como os poderes públicos têm tratado os povos indígenas até o presente. São nesses aspectos que encontramos contextos que vêm explicar o porquê dessa aparente supremacia da lei, logo do Estado enquanto seu executor, que acaba sendo imposta como algo natural e divino, e que principalmente aos índios, cabe exaltá-la. Por outro lado, em contrapartida a essa exaltação da lei e outras agências tutelares, é importante valorizar a realização de mobilizações como o Acampamento Terra Livre (ATL) que acontece anualmente desde 2004, para reivindicar a efetivação dos direitos conquistados e que não são executados como devem, além de exigir aqueles que ainda não atendem nossas necessidades. Se não deixa de se pedir a ação estatal pautando-se pela crença na democracia e na lei, é por uma iniciativa nossa. Isso porque é intensa a sensação de que o presente repete o passado em função dessa realidade: violências e violações de direitos dos povos indígenas e do meio ambiente devido à luta pela regulamentação e regularização dos territórios e igualmente, a expectativa na lei.

O estudo do Estado em sociedades contemporâneas (antigas metrópoles e antigas colônias) é recente na Antropologia, e ela não pode prescindir das contribuições da História, da Geografia, da Sociologia e da Filosofia. Não pretendo aqui fazer uma revisão bibliográfica sobre como a Antropologia e outras ciências concebem o Estado, já que me arriscaria a fazer uma leitura superficial. Mas que sob esses processos, se fez o Brasil do presente. 
O Estado - genericamente falando - é um dos mais importantes agentes de produção e transformação do espaço geográfico no desempenho de funções políticas, sociais e econômicas, sendo também um dos principais atores internacionais. O Estado corresponde ao conjunto de instituições no campo político e administrativo que organiza o espaço de uma coletividade humana, povo(s) ou nação(ões), com base no controle da taxação e do uso considerado legítimo da força física. A "garantia" do conjunto de valores que torna a ação do Estado legítima está expressa na legislação desde a Idade Moderna. Analisando o Estado a partir do caso do Brasil, podemos dizer que o Estado representa tudo o que é público dentro de um país, incluindo uma série de instituições.

O enfoque a partir do conceito de processos de formação de Estado (ELIAS, 2006) que compreende que o Estado se faz no cotidiano como rede de instituições e como crenças compartilhadas, nos leva a pensar que a gestão pública distribuída pelos "três poderes" (Legislativo, Executivo e Judiciário) não só é uma invenção, mas também que, na prática real, no plano da operacionalidade administrativa do Estado brasileiro para com os povos indígenas, existe uma linha espessa no sentido de que a implementação de políticas públicas, por exemplo, não é plenamente uma realidade, se não pela nossa insistência. Se, de algum modo, também nós indígenas estamos fazendo Estado é porque aprendemos na escola de modo que muitas vezes nos refletimos como "homens estatizados, servidores do Estado, que durante toda a sua vida, servem ao Estado e, assim, toda sua vida servem à contra-natureza (T. BERNHARD. Maftres anciens (Alte Meister KomOdie). Paris, Gallimard, 1988, p. 34, apud BOURDIEU, P., 1996, p. 92), porém, é importante destacar o quanto, por outro lado, agimos induzidos por falsas ideias.

Nessa perspectiva, se acentua a mentira e a omissão, sobretudo quanto aos direitos a que têm os povos indígenas e aos direitos estabelecidos para regulamentar a relação com o meio ambiente. Gestores de órgãos públicos propagam o discurso de que o meio ambiente é de uso comum a fim de diminuir a pressão que os povos indígenas fazem para implementação de políticas públicas e para concretização 
de direitos que afetam os nossos respectivos territórios e a natureza que nos cerca.

Como bem disse Teixeira (2014, p. 40) sobre segredos e mentiras quanto às dificuldades em etnografar instâncias estatais políticas e administrativas, "mentir ou omitir fatos é parte do jogo a ser jogado, como é o caso da vida política - podendo ser, inclusive, esperado ou defensável que eticamente, em certas circunstâncias, o político omita ou minta" (TEIXEIRA, 2014, p. 40), evocando a ética como o dever de verdade defendido por Weber (1999, p. 112). Teixeira, ainda se referindo a Weber (1999, p. 113), continua:

O político entenderá que essa maneira de agir (o dever absoluto da verdade), a julgar pelos resultados, longe de lançar luz sobre a verdade, irá obscurecê-la, pelos abusos e pelo desencadeamento de paixões que provocará [...] para dizer a verdade, se existe um problema (de) que a ética absoluta não se ocupa, esse é o problema das consequências. (TEIXEIRA, 2014, p. 40).

Mentir ou omitir é um tipo de conduta que está no cotidiano burocrático das instituições estatais, até muito naturalizada. A utilização desses elementos na relação de autoridades públicas com os indígenas é uma estratégia comum por parte dos gestores públicos, além do que são correspondentes a "fases da formação do Estado brasileiro" nas narrativas heroicas da história oficial,

as estruturas sociais variam profundamente de acordo com a medida de mentira que nelas operam (SIMMEL, 964, p. 312).

A mentira e a omissão nos modos de relacionamento entre colonizadores e indígenas no Brasil estão, pois, nessa genealogia. Como disse Ernest Gellner,

(...) a antropologia teórica não pode deixar de implicar uma visão do que somos, do que nossa sociedade é e do que pode vir a ser: os limites de formas possíveis de organização social constituem evidência crucial no que diz respeito a aspirações políticas, sejam elas sensatas ou absurdas. Os aspectos advin- 
dos nos dizem o que está e o que não está ao nosso alcance. (GELLNER, 1926, p. 7).

Por esse prisma, percebo como se originaram os modelos de administração e governança que atuam em relação aos povos indígenas no pleito pelo território e o meio ambiente através das leis, realizando essa análise a partir da presença indígena na história do Brasil.

Nesse sentido, compartilho o levantamento histórico resultado desta pesquisa o qual fornece elementos para elucidar o atual momento de luta política, trazendo uma cronologia sobre a regulamentação de direitos inseridos no ordenamento jurídico brasileiro que afetam povos indígenas ou que nos são direcionados. Assim como, nessa retrospectiva histórica, é acrescida uma análise sobre a formação do Estado brasileiro a fim de elencar categorias enquanto classificação de ideias, sobre como a composição legal nacional e internacional reconhecida pelo Estado passou a incidir sobre os povos indígenas e o meio ambiente, chegando ao presente em que se observa uma gama de propostas de revogação desses direitos que tramitam no Congresso Nacional.

Não se trata, pois, de detalhar genealogicamente o conceito de Estado nessas reflexões, e nem de longe revisar toda história oficial sobre o Brasil, tampouco propor uma atualização da Legislação Indigenista em vigor desde 2008, mas que a partir de instâncias estatais, são criadas e recriadas normas legais com base em prerrogativas elaboradas e reelaboradas a contento de seus "interlocutores", isto é, na maioria das vezes de forças políticas anti-indígenas. Tais medidas, de algum modo, são insídias que impactam somente os povos indígenas, afinal, argumentos são exaltados "em nome de" e não efetivamente "para", muito menos com os povos indígenas e o meio ambiente.

Não obstante, esses procedimentos sugerem que no cotidiano do fazer(-se) Estado se usa sistematicamente de artimanhas para forjar seu poder,

considerando que mentir ou omitir informações é esperado também dos funcionários políticos indicados pelos governantes 
que os colocaram em suas posições, em nome do alcance das metas de governo - políticas públicas e seus gestores políticos (TEIXEIRA, 2014, p. 40)

Isso se dá até mesmo no cumprimento, a rigor, da legislação indigenista "que sem dúvida, sinaliza que nem um nem outro movimento seja o da construção teórica, seja o da análise histórico-antropológica - pode ser descartado com facilidade" (SOUZA LIMA, 2012, p. 562), tampouco deixam de serem insinuados como algo "cultural" do Estado, de acordo com o que expõe Carneiro da Cunha ${ }^{6}$.

\section{PERCEPÇÃO E INSERÇÃO DO INDÍGENA NO ORDENAMENTO JURÍDICO BRASILEIRO}

Ao longo dos séculos, os mais diversos coletivos sociais no Brasil se tornaram o que são como resultados da relação dos povos indígenas com a Coroa portuguesa e, depois, com o Estado brasileiro na luta pelo território e o meio ambiente. O achamento do Brasil estabeleceu aos poucos, ao longo do tempo, regulamentações que legalizaram para fins do invasor português, depois brasileiro - a espoliação dos territórios indígenas. Como também "legitimaram" violências contra os povos indígenas e a exploração desordenada do meio ambiente e engessaram os indígenas numa ínfima condição social, cultural e espiritual. Se, como diz o ditado popular "manda quem pode e obedece quem tem juízo", aos indígenas desobedecer podia e pode condizer mais uma vez com o custo da própria vida/etnia/raça.

Considerando que a presente investigação se volta para a genealogia da legislação colonial portuguesa e depois brasileira pelo longo e penoso processo de percepção e inserção de indígenas e do meio ambiente ao ordenamento jurídico brasileiro, vou abordá-las descrevendo-as em três intervalos distintos:

6 Carneiro da Cunha, M. "Cultura" e cultura: conhecimentos tradicionais e direitos intelectuais. 2009. 
I) O primeiro tempo compreende de 1511 a 1910, mais longo e lento por apontar entendimentos, causas, razões, circunstâncias, presenças e participações no processo de construção sociocultural e socioambiental espacial do Brasil;

II) O segundo tempo por ter uma estrutura sociofuncional estatal e econômica, foi trabalhado com um intervalo temporal menor, qual seja de 1910 a 1988, basicamente a partir da criação do Serviço de Proteção ao Índio e Localização dos Trabalhadores Nacionais (SPILTN - 1910/1918-1967) e do Código Civil Brasileiro/1916 até a publicação da Carta Magna/1988; e

III) O terceiro tempo aparente de menor tempo é, na verdade, o resultado mais recente e significativo da luta entre os povos indígenas e o Estado brasileiro, do choque direto entre a pretensa autonomia e a superação da tutela cada vez mais contemporânea: a incidência da Constituição Federal de 1988 para os povos indígenas.

\subsection{O PERÍODO DE 1500 A 1910}

Segundo Pacheco de Oliveira \& Freire (2006, pp. 35-37), a legislação colonial e os interesses comerciais da Coroa portuguesa com relação aos povos indígenas (intrinsecamente, ao meio ambiente), foram orientados sob ideias de paganismo, selvageria e barbárie presentes no imaginário cristão medieval, pois

A legislação da colônia era subordinada à legislação metropolitana. Assim funcionava aquele sistema jurídico. Com o auxílio de conselhos consultivos - a Mesa de Consciência e Ordens (1532), o Conselho da Índia (1603) e o Conselho Ultramarino (1643) - o rei definia os Regimentos dos governadores gerais do Brasil e estabelecia leis através de Cartas Régias, Alvarás etc. A legislação da Coroa que atingia os gentios era regulamentada

7 Os autores não tratam sobre o meio ambiente, mas tratar de território indígena é tratar da natureza. 
na colônia pelos governadores gerais através de Decretos e Alvarás. (PACHECO DE OLIVEIRA \& FREIRE, 2006, p. 36).

Havia também a legislação sobre as "guerras justas", que consistia em uma doutrina que autorizava a Coroa e a Igreja a declararem guerra aos índios pagãos que deveriam ser catequisados e civilizados, tornando-se "vassalos d'El Rei", os índios eram trazidos de suas aldeias forçadamente. Sobre "guerra biológica", trata-se da conquista dos povos indígenas na época colonial que contou com o recurso da disseminação de doenças e a ocorrência de epidemias para as quais os povos em guerra ou dominados tinham baixa imunidade ${ }^{9}$, além da sucessão de envenenamentos.

Foram mais de três séculos (1511-1831) com 24 regulamentações escravistas para povos indígenas, usando de todos os meios para manter os autóctones sob o domínio português e da igreja para regozijarem de seus territórios. Mas também tivemos 20 regulamentos contra a escravização de indígenas a partir da Bula do Papa Paulo III, em 1537 e a última em 27 de outubro de 1831, pela Lei $n^{\circ} 27$ que aboliu definitivamente, no plano jurídico apenas, o cativeiro e a servidão indígena no $\mathrm{Brasil}^{10}$. Sobre a questão territorial, havia apenas 14 regulamentações sobre terras indígenas (dentre essas, 3 que não concediam terra aos indígenas) entre 1562 e 1891, quando se deu a promulgação da primeira Constituição Federal Republicana ${ }^{11}$. No entanto, a prática de proteção aos indígenas se distanciava das normativas decretadas.

8 Essa expressão é tocada por Pacheco de Oliveira \& Freire, 2006, p. 36-37.

9 Ibid, p. 123.

10 Ibid, p. 208; 222. [Cronologia, 1994].

11 Apenas uma observação: É importante destacar que antes da Constituição Federal Republicana, publicada em 24 de fevereiro de 1891, havia a Constituição Política do Império do Brasil, promulgada em 25 de março de 1824. Nenhuma das duas Constituições trata da questão indígena, nem mesmo sobre o território nessa perspectiva. A possível, porém, remota, referência que ambas as Constituições possam ter trazido sobre a questão indígena está na Constituição/1824, o art. 179, XIX ("Desde já ficam abolidos os açoites, a tortura, a marca de ferro quente, e todas as mais penas crueis"). E na Constituição/1891, apenas o art. 72, $\S 1^{\circ}$ ("Ninguem póde ser obrigado a fazer, ou deixar fazer alguma cousa, senão em virtude de lei"). 
Muitas dessas lembranças reavivadas durante a I Conferência Nacional de Política Indigenista ocorrida em $2015^{12}$ expuseram a flor da pele a com a mesma intensidade, emoções da luta e resistência de indígenas desde o período colonial, ou de grupos indígenas que se juntaram e se ressignificaram como povos indígenas movidos pela essência de pertencimento à natureza. Momentos como esse também foram lembrados quando participava dos Planos de Gestão Ambiental e Territorial (PGTA's) na Terra Indígena llha de São Pedro (SE) e em Pankararu (PE) nas Terras Indígenas Entre Serras Pankararu e Pankararu.

Somando-se a essas lembranças, seguem duas histórias que demonstram que, independentemente do povo, do lugar ou da época, a questão é a percepção e inserção da figura indígena no ordenamento jurídico colonial português que, desde 1511, vem afetando a vida e a história dos povos indígenas em todo o Brasil.

O primeiro caso aconteceu em Belém, capital do Estado do Grão-Pará e Rio Negro. Refere-se à história da índia Josefa Martinha, como citada pela historiadora Patricia Melo Sampaio, que se valeu da Lei de Liberdade dos Índios (Lei de 06.06.1755, tornada pública em 28.05.1757) ${ }^{13}$. Sua coragem e atitude ao requerer sua liberdade à rainha $\mathrm{D}$. Maria I despertaram outro olhar sob a população indígena,

a presença sistemática das populações indígenas colocando questões novas ao universo jurídico português, demandando a elaboração de uma legislação específica para essas populações a fim de definir os lugares que os povos indígenas deveriam ocupar no novo mundo que se pretendia construir a colônia [...] De acordo com os especialistas, uma análise do extenso repertório legal produzido ao longo dos séculos de colonização indica que a liberdade dos índios foi, na verdade, a base de toda legislação indigenista colonial ${ }^{14}$. (SAMPAIO, 2014, p. 32)

12 Ver capítulo II.

13 Sampaio, 2014, p. 32: Arquivo Histórico Ultramarino (AHU), ACL, CU13, Cx. 82, doc. 6.716.

14 Apud PERRONE-MOISÉS, 2000, p. 148. 
Entretanto, a "fábula"15 da Lei de Liberdade ainda não seria o instrumento que garantiria ao Estado o controle sobre os povos indígenas. Assim é que surge a categoria da tutela como unidade de poder, coerção e comando sobre os povos indígenas. Para que isso fosse possível, foi cimentada que a capacidade mental dos indígenas era tão inferior que era indispensável que ficassem sob o amparo do Estado. Enquanto isso acontecia, eram na prática realizados saques maciços de territórios, dos bens e recursos naturais dos povos indígenas.

As consequências reais da Lei de Liberdade se deram em alguns níveis. Num primeiro nível, a legislação colonial não tinha como manter o controle dos índios "libertados", se não se criasse alguma forma "legal" de manter a subserviência (para não dizer escravidão) dos libertos, ainda que fossem considerados alienados por se recusarem ao trabalho.

O segundo nível diz respeito ao modo como foi entendida e interpretada a figura jurídica da tutela no mundo colonial brasileiro, arbitrada e acompanhada pelo Juízo dos Órfãos na segunda metade do século XVIII, ainda que se tratasse de uma solução temporária para normalizar um período de transição.

O terceiro nível tem a ver com o fato de que de 29.01.1549 pelo Regimento do $1^{\circ}$ Governador Tomé de Souza, que recomendava o "cuidado dos índios"16, a 12.05.1798 (Carta Régia da rainha D. Maria I), a Coroa portuguesa se preocupou em manter vigiada e controlada a liberdade dos indígenas que não tinham sido capturados e aqueles que estivessem sido contemplados pela Lei de Liberdade. Até porque, nesse interim, já havia sido instaurado o 'precedente' no estatuto tutelar imposto no Diretório dos Índios (Diretório de 03.05.1757) às populações recém-aldeadas nas vilas coloniais, bem como havia a proclamação do regimento que colocava os índios livres sob a jurisdição do Juízo dos Órfãos (Bando de 28.05.1757) ${ }^{17}$.

15 Quando digo fábula é que a Lei de Liberdade na verdade era uma proposta do indígena sair da condição de escravo para vassalo. A Lei de Liberdade não dava nenhum outro amparo, induzia uma liberdade marginal e que a única via de conseguir alguma assistência era voltar a "servir" aos poderosos da época.

16 Pacheco de Oliveira \& Freire, 2006, p. 209 [Beozzo, 1983; Ribeiro, 1983].

17 Sampaio, 2014, pp. 34-35. 
Na ótica da administração colonial, o Diretório pode ser analisado como um instrumento tutelar temporário com vigência de 07 anos e necessário de transição para a liberdade, considerando o estado inicial da civilização dos índios recém-aldeados, posteriormente coloca-os sob a tutela dos juízes de órfãos. A Carta Régia, por seu lado, vinha "suprir" a temporalidade expirada do Diretório e poderia ser aferida na medida em que os índios alcançassem a "capacidade mental" de poder servir como vassalos. Então, escravização, catequização, liberdade e tutela caminhavam juntas no trato com as populações indígenas e, novamente, a diferença estava na "capacidade mental" de civilidade, expressa pelos instrumentos legais, para servir como soldado ou vassalo imperial com suas fazendas e dízimos ${ }^{18}$.

Mesmo assim, era fundamental encontrar um ponto no qual se pudesse assegurar que o índio não tinha essa capacidade mental, e o "Termo de Educação e Instrução"19, de certa forma, trazia esse controle por sua formulação temporal de concessão de liberdade. Enquanto isso, a extensão do estatuto tutelar manteve-se em função de promover assistencialismo aos indígenas declarados órfãos, isto é, aqueles sem território; e aqueles considerados sem civilidade alguma. Comparando à proteção de crianças e parafraseando Vianna (2014), nessa concepção de tutela, a autoridade de descrever/prescrever a legitimidade de certas relações em detrimento de outras e de definir em nome desses recém-proclamados "sujeitos de direito" cabia à Coroa portuguesa (Estado), a quem pertencia o poder e subsequentemente a obrigação de "guardá-los" e "protegê-los" de um destino mais trágico. É importante apontar o quanto isso era contraditório, na mesma medida em que os indígenas estavam sob o controle da Coroa e da igreja.

Chegando ao Nordeste, a narrativa trazida por Martha Priscylla Monteiro Joca Martins, sob a ótica da colonização e do esbulho territorial nesta região, é muito familiar. A autora afirma que o contato no

18 Sampaio, 2014, p. 48; Pacheco de Oliveira \& Freire, 2006.

19 Segundo Sampaio (2014, p. 45), o referido Termo era uma modalidade de tutela particular e individual, cujo compromisso de quem capturasse os indígenas, era batizar e educar para o trabalho serviu ao seu encarcerador. Qualquer pessoa podia aprisionar indígenas, bastando requerer às Câmaras o respetivo Termo. 
Ceará também se deu por processos de silenciamento e violências. Segundo Joca (2011, p. 68), no trabalho realizado por Izabelle Braz em $2009^{20}$, revela-se a inclusão do "Relatório Provincial apresentado pelo Presidente José Bento da Cunha Figueiredo à Assembleia Legislativa do Ceará por ocasião de sua instalação" (1863), o qual tratava de assuntos diversos, dentre estes, terras públicas e aldeamentos. Conforme Joca, o Relatório sobre aldeamentos indígenas enuncia que

Já não existem aqui índios aldeados ou bravios. Das antigas tribos de Tabajaras, Cariris e Pitaguaris, que habitavam a província, uma parte foi destruída, outra emigrou e o resto constituiu os aldeamentos da Ibiapaba, que os jesuítas no princípio do século passado formaram em Vila Viçosa, S. Pedro de Ibiapina, e S. Benedito com os índios chamados Camussis, Anacaz, Ararius e Acaracú, todos da grande família Tabajara. Com a extinção dos jesuítas, que os governavam teocráticamente, decaíram esses aldeamentos, e já em 1813 informava um ouvidor ao governador Sampaio que os índios iam-se extinguindo na Ibiapaba, onde tinham aqueles religiosos um célebre hospício no lugar denominado Vila Viçosa, que com os outros acima indicados abrangem a comarca deste nome. É neles que ainda hoje se encontra maior número de descendentes das antigas raças; mas acham-se hoje misturados na massa geral da população, composta na máxima parte de forasteiros, que excedendo-os em número, riqueza e indústria, tem havido por usurpação ou compra as terras pertencentes aos aborígenes. A mesma sorte que as da lbiapaba tiveram as aldeias da capital, compreendidas as da antiga vila de Aquiraz (onde existiu o hospício dos jesuítas, fundado no princípio do século passado), Mecejana (missão de Paupina), Arronches (missão de Parangaba), Soure (missão de Caucaia), e Monte-mór Velho (missão dos Paijacús). Os respectivos patrimônios territoriais foram mandados incorporar à fazenda por ordem imperial, respeitando-se as posses de alguns índios. O que se diz a respeito dessas aldeias é tam-

20 BRAZ, Isabelle. O Relatório Provincial de 1863: um documento, muitas leituras. Trabalho apresentado no XXV Simpósio Nacional de História, Simpósio Temático 36: Os Índios na História, 2009, Fortaleza. Disponível em: <http://www.ifch.unicamp.br/ihb/Trabalhos/ ST36lsabelle.pdf >; acesso em 16 nov. 2017. 
bém aplicável às dos Trambabes (Almofala) no termo do Acaracú, dos Jucás (Arneiroz) do termo de S. João do Príncipe, e dos Cariris (Missão Velha e de Miranda) hoje Crato. No ano de 1860 Manuel José de Souza, do termo de Milagres, aldeou os restos a uma antiga tribo de índios chocos, em número de 28 , que erravam, perseguidos, entre os limites das províncias de Pernanbuco, Parahyba e Ceará. [...] Tais são, em resumo, os esclarecimentos que sobre aldeamentos ministrou-me o diligente autor da Estatística, em ofício de 21 de julho do ano passado. (Relatório Provincial de 09 de outubro de 1863. Relatórios dos Presidentes da Província. BPGMP. Núcleo de microfilmagem). (BRAZ, 2009, pp. 2-3 apud JOCA, 2011, pp. 68-69)".

Ainda segundo Joca (2011, p. 70), em 1878, em carta escrita pelo Ministro do Império ao Presidente da Província do Ceará, a afirmação é confirmada:

Tendo deixado de existir, de fato, aldeamentos, que foram fundados nessa província, em data recente ou remota, por se haverem dispersado seus habitantes ou fundido nas outras classes, remetam ao ministério ao meu cargo quantos esclarecimentos for possível para revelar a criação dos terrenos que constituíram tais aldeamentos ${ }^{21}$.

O documento de 1863 é percebido como um instrumento que ratifica a Lei de Terras $(1850)^{22}$, segundo a qual se institucionalizava a terra

21 Informação disponível em <http://www.ecodebate.com.br/2008/12/22/o-reconhecimentodas-etnias-indigenas-no-ceara-passa-pela-demarcacao-de-suas-terras/>; acesso em 16 nov. 2017.

22 A Lei de Terras, como ficou conhecida a lei $n^{\circ} 601$ de 18 de setembro de 1850, foi a primeira iniciativa no sentido de organizar a propriedade privada no Brasil. Até então, não havia nenhum documento específico que regulamentasse a posse de terras e com as modificações sociais e econômicas pelas quais passava o país, o governo se viu pressionado a organizar esta questão. No Brasil, a Lei de Terras foi uma das primeiras leis brasileiras, após a independência do Brasil (um processo que se estendeu de 1821 a 1825; a independência foi proclamada em 07 de setembro de 1822), a dispor sobre normas do direito agrário brasileiro. A Lei de Terras trata-se de uma legislação específica para a questão fundiária. Esta lei estabelecia a compra como a única forma de acesso à terra e abolia, em definitivo, o regime de sesmarias. Muito embora não tenha havido revogação formal, considera-se que a mesma foi derrogada quando da edição da Lei $n^{\circ} 4.504$, de 30 
como mercadoria e propriedade privada, ainda que reservasse uma parte das terras devolutas para a "colonização dos indígenas". Assim, o objetivo era declarar que não havia mais índios no Ceará, porque as terras ficariam à disposição da apropriação privada e criação de cidades $^{23}$. Desde o Período Colonial, o direito das sociedades indígenas a terra foi sucessivamente reconhecido pelas leis no Brasil. Joca, ainda se referindo ao trabalho de Braz, reflete que

Apesar disso, ao longo dos séculos as terras indígenas foram permanentemente espoliadas. Objeto da cobiça dos latifundiários em grande parte das situações, as terras indígenas foram tratadas na maioria das vezes como "terras de ninguém". Terra de ninguém não só pelo descaso com que eram tratados os seus ocupantes - um "zé ninguém" - , mas pela literal desconsideração destes: se não era possível desconhecer o Direito, tratava-se de não reconhecer o sujeito desse Direito. Se não era possível ignorar o direito dos índios a terra, trata-se de negar a existência desses índios. (BRAZ, 2009, p. 9 apud JOCA, 2011, p. 70).

Todavia, a exemplo do Pará24, o Ceará não foi o único Estado a traçar essa história, pelo contrário, todas as leis que partiram daquelas realidades surtiram efeito em todos os povos indígenas do Brasil, e no caso do Ceará, em todos os povos indígenas da região Nordeste. Afinal, a história dos povos indígenas do Ceará denuncia a negação de territórios indígenas pela negação da identidade racial, o que, por sua

de novembro de 1964 (o "Estatuto da Terra"), que trata do mesmo assunto. A Lei de terras teve origem em um projeto de lei apresentado ao Conselho de Estado do Império em 1943, por Bernardo Pereira de Vasconcelos. A Lei de Terras foi regulamentada, em 30 de janeiro de 1854, pelo Decreto Imperial $n^{\circ} 1.318$.

Art. 12. O Governo reservará, das terras devolutas, as que julgar necessárias: $1^{\circ}$, para a colonização dos indígenas [...].

(Fonte: https://pt.wikipedia.org/wiki/Lei_de_Terras;

https://pt.wikipedia.org/wiki/Independ\%C3\%AAncia_do_Brasil). Acesso em 16 nov. 2017.

23 "Em ofício de 1859, [...] a Tesouraria da Fazenda [do Ceará] representava ao Governo Imperial "já não existem ali hordas de índios selvagens e acham-se descendentes destes confundidos na massa da população civilizada". O que autorizava a mesma Tesouraria, em relação às terras indígenas "expedir ordens para que elas fossem sequestradas e incorporadas aos próprios nacionais"”. (JOCA, 2011, p. 70).

O caso da índia Josefa Martinha. 
vez, viabiliza a expansão econômica e o domínio de terras indígenas, dos bens e recursos naturais.

De igual forma, outros estados do Nordeste passavam pelos mesmos procedimentos de dizimação territorial, cultural e tradicional dos indígenas, induzindo à construção de uma base populacional sem origem, sem vínculo, "sem dono", submissos ao coronelismo e ao patriarcado vigente. A criação de uma instância governamental voltada para dar atenção aos indígenas somente no ano de 1910 não diminuiu trais atrocidades. E, desde sempre, a luta pelo território e pelo meio ambiente, bem de uso comum dos povos originários e essencial à sadia qualidade de vida, tem sido a bandeira de luta dos povos indígenas do Brasil.

\subsection{INTERVALO TEMPORAL DE 1910 A 1988}

A história iniciada pela índia Josefa toma propositadamente um espaçamento muito grande para chegar ao segundo momento histórico (1910-1988), se refletindo no Código Civil Brasileiro (CCB) de 1916 no que tange a tutela. Este Código ratifica a tutela atrelada à capacidade civil, definida como a aptidão da pessoa para exercer direitos e assumir obrigações ${ }^{25}$. Segundo o CCB/1916, entende-se por incapacidade absoluta aqueles que não podem praticar os atos da vida civil senão através de um representante legal; diz-se incapacidade relativa quando o indivíduo se encontra num patamar entre absolutamente incapaz e o plenamente capaz, e pode praticar os atos da vida civil desde que assistidos pelo representante legal.

Ressalte-se que na representação, o ato é praticado pelo representante em nome do incapaz, sem a sua participação; na assistência, o ato é praticado pelo próprio incapaz, mas na presença do represen-

25 No direito civil, há certas pessoas que a lei qualifica como incapazes para atos da vida civil, são elas dotadas de prerrogativas de serem titulares de direito, mas não podem, por elas mesmas, exercer estes direitos, necessitando ser representadas ou assistidas por um responsável. O objetivo é proteger os interesses dos incapazes, que não possuem um grau de maturidade para os negócios da vida civil, poderiam estar desamparados e ser influenciados por pessoas mal-intencionadas. A lei distingue os incapazes em absolutos ou relativos, mas tal classificação é decorrente apenas de uma presunção de grau de discernimento do indivíduo. 
tante legal e adverte que o ato praticado pelo relativamente incapaz é anulável, não é nulo. Essas recomendações orientaram a tutela voltada aos povos indígenas regulamentadas posteriormente pelo Estatuto do Índio (Lei n 6.001, de 19.12.1973).

Não obstante, segundo Souza Lima ${ }^{26}$, passados três séculos o primeiro instrumento legal a regular tal função de identificação e hierarquização espacializada foi gerado pelo conjunto de atores que implantou o SPI, e se transformou na Lei $n^{0} 5.484 / 1928(27.06 .1928)^{27}$, que se pode considerar o primeiro estatuto do índio republicano ${ }^{28}$. Por muitos anos a instituição da tutela foi a única via de assistência do Estado brasileiro para com os povos indígenas, quer tenha sido pelo Serviço de Proteção ao Índio e Localização dos Trabalhadores Nacionais (SPILTN/1910) ou Serviço de Proteção ao Índio (SPI/1918), quer seja pela Fundação Nacional do Índio (FUNAI/1967) ${ }^{29}$. A FUNAI herdou as arbitrariedades do SPI e ao final da década de 1960,

a principal preocupação de seus dirigentes passou a ser a implementação de projetos econômicos (agrícolas, de criação de gado, de extração de madeira etc.) a comercialização de artesanato e contratos de arrendamentos, que compunham a renda indígena. A perspectiva era então de transformar o exercício da tutela em um gerenciamento de bens (terra, trabalho e outros serviços) referidos como sendo de posse e usufruto exclusivo do índio, tendo em vista desse modo tornar a assistência ao

26 SOUZA LIMA, Antonio Carlos. In: "A pacificação como prática de poder no contexto da criação do Serviço de Proteção aos Índios". 2009, p. 3-4.

27 "Regulamentou a situação dos índios nascidos no território nacional" (Pacheco de Oliveira \& Freire, 2006, p. 227 [Oliveira, 1994, pp. 131-141]).

28 Mais informações podem ser encontradas em SOUZA LIMA, 2009, pp. 3-4; 2014, pp. 6869; 2015, p. 432.

29 Segundo Souza Lima, "pode-se dizer que o exercício de poder tutelar deve ser pensando como se interagisse tanto elementos das sociedades de soberania quanto das disciplinares, mas é antes de tudo um poder estatizador em agências que se opõem a ter abrangência "nacional", isto é, estende-se enquanto malha administrativa por todo o mapa político do País, até porque o exercício do poder tutelar implica(va), pois, obter o monopólio dos atos de definir e controlar o que são as coletividades sobre as quais incidirá" (SOUZA LIMA, 2014, pp. 67-68). 
índio uma atividade autofinanciável para a burocracia estatal. (PACHECO DE OLIVEIRA \& ALMEIDA, 1998, pp. 71-72).

A criação de uma instituição estatal para promoção e proteção dos povos indígenas e consequentemente do meio ambiente trouxe na sua essência toda perversidade no trato aos índios desde o período colonial. Se por um lado o Brasil reconhecia direito aos povos indígenas e ao meio ambiente, por outro, implantava uma política de extermínio e usurpação. As pacificações, as frentes de expansão, trabalhos de atração de indígenas, epidemias, massacres e tutela, foram por muitos anos o carro-chefe do SPI e da FUNAI, enquanto que a regularização de territórios estava em último lugar. Todavia,

a passagem do século XIX para o XX importava para a classe dominante brasileira, alguns desafios à manutenção de sua hegemonia sob um novo quadro histórico, caracterizado por mudanças importantes que se implantaram em ritmos e tempos distintos. Dentre estas mudanças, três das mais significativas foram: 1) o término jurídico da escravidão e a necessidade de instauração de uma ordem baseada na liberdade, ainda assim mantendo controle sobre o acesso a terra e sobre a força de trabalho de estratos sociais hierarquicamente inferiores da população, em especial os libertos e seus descendentes; 2) a necessidade de construção efetiva de um aparato administrativo de Estado, com o fim do Real Padroado, logo, do papel de "unidades administrativas mínimas", desempenhado por longo tempo pelas paróquias (com a paralela redefinição ou o surgimento de unidades administrativas propriamente eclesiásticas sobre certos segmentos sociais); 3) a redefinição dos modos de se imaginar e de se pertencer a uma comunidade política nacional sob um regime republicano federativo. (SOUZA LIMA, 2015, p. 428).

Nesse sentido, podemos perceber como se constituiu o modelo de gestão em si tratando de política indigenista. Ainda assim, o órgão indigenista passou a ser mais e mais, a opção número um dos povos indígenas, os quais vêm recorrendo ao órgão a fim de reivindicar suas demandas, como a regularização territorial, dentre outras. Não obstante, em 19 de dezembro de 1973 se promulgava a (capciosa) Lei $n^{\circ}$ 
6.001, conhecida como Estatuto do Índio, dispondo sobre as relações do Estado e da sociedade com os povos indígenas e garantindo "aos índios e comunidades indígenas, nos termos da Constituição, a posse permanente das terras que habitam, reconhecendo-Ihes o direito ao usufruto exclusivo das riquezas naturais e de todas as utilidades naquelas terras existentes" 30 .

O Estatuto do Índio confirmou as recomendações do Código Civil Brasileiro de 1916 e em parte do Decreto $n^{\circ} 5.484 / 1928^{31}$, tendo como objetivo "regular a situação jurídica dos índios e das comunidades indígenas, com o propósito de preservar a sua cultura e integrá-los, progressiva e harmonicamente, à comunhão nacional"32. Para isso, estipulou uma escala de integração à sociedade nacional para que com isso os indígenas pudessem adquirir os mesmos direitos e benefícios dos demais brasileiros, resguardando os usos, costumes e tradições.

Confirmando o art. $4^{\circ}$, parágrafo único do Código Civil Brasileiro/1916, a proposta do Estatuto do Índio trouxe a ratificação de tal dispositivo sobre a tutela também no artigo $4^{\circ}$ explicitando as transições (mentais) de classificação de indianidade, segundo seu grau de integração à sociedade:

I - Isolados - Quando vivem em grupos desconhecidos ou de que se possuem poucos e vagos informes através de contatos eventuais com elementos da comunhão nacional;

II - Em vias de integração - Quando, em contato intermitente ou permanente com grupos estranhos, conservem menor ou maior parte das condições de sua vida nativa, mas aceitam algumas práticas e modos de existência comuns aos demais setores da comunhão nacional, da qual vão necessitando cada vez mais para o próprio sustento;

III - Integrados - Quando incorporados à comunhão nacional e reconhecidos no pleno exercício dos direitos civis, ainda que

30 Art. $2^{\circ}$, IX, da Lei ${ }^{\circ} 6001$, de 19.12.1973.

31 Souza Lima, 2009, pp. 3-4.

32 Art. $1^{\circ}$, da Lei 6.001 , de 19.12.1973. 
conservem usos, costumes e tradições característicos da sua cultura. (ESTATUTO DO ÍNDIO, 1973).

Essa classificação não é apenas uma recomendação legal. Eu penso que é, sobretudo, um instrumento de dupla marginalização dos povos indígenas, sem considerar os processos de violência que sofreram desde a colonização: marginalização pela implícita segregação social, econômica e biológica racial; e marginalização porque desapropria de seus territórios originários, levando à criminalização de indígenas. A "integração à comunhão nacional" representava a desobrigação do Estado com o indígena, além do que seria a confirmação de que não seria reivindicado seu "antigo" território e desta forma haver a exploração econômica sobre o meio ambiente, sem preocupações.

No que concerne ao Estatuto do Índio, será essa a razão que ensejou o artigo $19^{33}$ passando por 05 regulamentações até chegar a $6^{\mathrm{a}}, 23$ anos depois? Teria sido o motivo que influenciou o artigo $33^{34}$ sobre aqueles indígenas para obter a propriedade plena de seus territórios? Também esse seria o motivo sobre a efetividade do artigo $65^{35}$ ? Sobre essa última pergunta, Pacheco de Oliveira \& Almeida (1998) trazem brilhantemente muita informação. O Estatuto em seus 68 artigos regulamenta a política do integracionismo adotada no Brasil para incorporar os indígenas aos demais brasileiros, mas, de olho nos territórios ${ }^{36}$.

Mesmo sob pressão política e econômica e demasiado controle estatal, os povos indígenas conseguiram "furar" essas barreiras desencadeando a partir da década de 1970 a articulação de líderes indígenas em todo o Brasil a reivindicação do "direito aos direitos", movimento que tomou proporções internacionais e ficou conhecido como Movimento

33 Art. 19: "As terras indígenas, por iniciativa e sob orientação do órgão federal de assistência ao índio, serão administrativamente demarcadas, de acordo com o processo estabelecido em decreto do Poder Executivo". (Estatuto de Índio/1973)

34 Art. 33: "O índio, integrado ou não, que ocupe como próprio, por dez anos consecutivos, trecho de terra inferior a cinquenta hectares, adquirir-lhe-á a propriedade plena". (Estatuto de Índio/1973)

35 Art. 65: "O Poder Executivo fará, no prazo de cinco anos, a demarcação das terras indígenas, ainda não demarcadas". (Estatuto de Índio/1973)

36 A lógica era: se os indígenas estão "integrados", não precisam mais possuir terras. 
Constituinte, o qual consolidou direitos fundamentais, sociais, territoriais e ambientais reconhecidos na Nova Constituição da República Federativa do Brasil, promulgada em 05 de outubro de 1988.

\subsection{A CONSTITUIÇÃO FEDERAL DE 1988}

Nesse terceiro momento temporal, a Constituição Federal de 1988 sinaliza novos tempos para os povos indígenas ao proclamar nossa autodeterminação e a nossa autonomia. Não é preciso repetir toda mobilização que ensejou o capítulo da Constituição Federal voltado aos índios. Mas, para além desses dois artigos, partindo do pressuposto que os povos indígenas usufruem os mesmos direitos civis e políticos de todos os cidadãos brasileiros, sem deixar de abrir mão de nossas culturas e tradições, a Constituição traz um significado de pertencimento de nós indígenas enquanto cidadãos brasileiros.

Tudo o que antes se fazia timidamente como registro de nascimento, título de eleitor, candidatura eleitoral, filiação partidária, a continuação nos estudos, enfim, pôde ser executado com mais convicção, pois a barreira da escala de indianidade prescrita no Estatuto do Índio foi (teoricamente) derrubada e pela primeira vez em muito tempo. Nós índios passamos a ter a oportunidade de sermos donos de nós mesmos, de retomarmos nossas tradições, de reclamarmos nosso território, de não termos que "abdicar" de nossas origens, porque na verdade, nunca abdicamos.

Foi nesse contexto pós-constitucional que surgiram com maior ímpeto demandas sobre educação, saúde, segurança, alimentação, meio ambiente e regularização territorial, bem como ampliou-se a nossa participação em espaços políticos e promovemos uma busca por nos prepararmos para esses debates. Cresceu o número de associações indígenas, começou-se a construir qual seria o modelo - ou modelos específicos e diferenciados - de auto sustentabilidade socioculturais e socioambientais para as comunidades indígenas.

No entanto, quanto à tutela, o novo Código Civil em vigor desde 10 de janeiro de 2002 ratifica o artigo $4^{\circ}$, parágrafo único, que define que 
a capacidade "dos indígenas"37 será regulada por legislação especial. Na prática, essa ideia continuou sendo a Lei 6.001/1973, mantendo a tutela da União, por intermédio da FUNAI, que é o órgão competente de assistência e representação (Lei no 5.371, de 05.12.67).

De modo gradativo, eloquente, e nem tanto suave, o Estado brasileiro se manteve na condução e manutenção dos povos indígenas, apregoando que a tutela era (é!) fulcral à existência indígena. Pensando na FUNAI, posso dizer que existe uma certa "confabulação estatal" para a alienação do indígena, para os não-indígenas se manterem no poder usando a barganha seja do assistencialismo, seja da representatividade que os povos indígenas tanto buscam no órgão indigenista e até em outras instâncias. Esta é a tutela contemporânea: está no fazer Estado com povos indígenas. Não pretendo adentrar setor por setor, mas destacar como a tutela nunca deixou de existir e está muito longe de acabar.

Nota-se que a via mais prática do Estado manter a tutela contemporânea é cooptar o indígena e persuadi-lo a acreditar que ele é parte do Estado por compor seus quadros funcionais, além também de envaidecê-lo pela quimera de representar o Estado. O crivo da capacidade mental ainda é cronômetro do desempenho intelectual e social de modo que, muitas vezes, permitir que o índio "exerça sua autonomia" realizando tarefas de gestão do aparelho público, é esperar no fundo que não aconteça e, se não funciona, melhor para o Estado porque endossa seu discurso que o índio continua incapaz, portanto, necessário se faz continuar assistenciando e representando-o em seu cotidiano, o argumento persuasivo na manutenção da tutela.

Trazer os efeitos da Constituição Federal/88 para os povos indígenas não se esgotam aqui, até porque essa exposição é um brevíssimo começo. E, se antes a nossa luta era por conquistas (que ainda é), hoje é também pelo respeito e manutenção, ressalvando os embates políticos contra as medidas anti-indígenas que tramitam no Congresso Nacional.

Então, diga ao povo que avance...

37 Curiosamente, a nova redação "dos índios" para "dos indígenas" foi regulamentada no art. 114, da Lei 13.146, de 06 de julho de 2015, que institui a Lei Brasileira de Inclusão da Pessoa com Deficiência (Estatuto da Pessoa com Deficiência). 


\section{PROCESSOS DE FORMAÇÃO DO ESTADO BRASILEIRO: A FORMAÇÃO DA "PERSONALIDADE POLÍTICA" DO BRASIL ANTE AS PRIMEIRAS RELAÇÕES COM OS POVOS INDÍGENAS}

Há mais de cinco séculos, os povos indígenas têm tido perdas significativas e diria até irreparáveis quanto à posse de nossos territórios e, consequentemente, na relação com o meio ambiente, fundamental para os modos de vida tradicionais, socioculturais e socioambientais. Embora José Bonifácio de Andrade e Silva ${ }^{38}$ tenha declarado que os índios deveriam gozar dos "privilégios da raça branca", inclusive de seus territórios, essa medida não foi acatada.

Assim, pensar uma linha histórica sobre os povos indígenas e o Estado brasileiro na luta pelo território e o meio ambiente é pensar na própria formação do Estado brasileiro, e considerar como gradativamente foi se formando uma imagem do Estado para os povos indígenas, que chega mesmo a parecer, sobretudo para nós indígenas, uma "personalidade política do Brasil".

Essa imagem foi se formando a partir dos processos que se constituíram pelo regime de feitorias ${ }^{39}$, pelos chamados ciclos ${ }^{40}$ econômicos, pela ação das frentes de expansão, pela fricção interétnica, pelas ações de pacificação, catequização, aculturação e pela pérfida tutela. Eu entendo que esses elementos das relações com os colonizadores estão presentes em situações desde a genealogia do contato com os povos indígenas e que podem ser percebidas na atualidade com outros nomes. Vou chamar esses elementos de categorias de contato, como sendo um conjunto de situações que se deram na história de relações entre povos indígenas com a formação do Estado brasileiro.

38 Pacheco de Oliveira; Freire, 2006, p. 102-103.

39 Pacheco de Oliveira, 2016, p. 50.

40 Para Pacheco de Oliveira (2016: 47), a noção de "ciclo" é um instrumento aparentemente cômodo, que terá como função descrever a diversidade de formas econômicas e societárias registradas na história. 
Quando leio a história das relações do colonizador com os povos indígenas penso que as frentes de expansão hoje são percebidas nos projetos de empreendimentos do Governo Federal, do agronegócio e da mineração; a friç̧ão interétnica se faz no esforço de integração de diferentes culturas/conhecimentos a realidades que os indígenas adaptaram ao seu cotidiano; pacificação hoje são os contingentes policiais que invadem terras ocupadas por indígenas a fim de expulsá-los, ainda que para isso executem indígenas, em favor dos grandes espoliadores de suas terras; a catequização, atualmente é mais a conversão às igrejas evangélicas que tem afastado os indígenas de viver em suas culturas e tradições; a aculturação, de conceito antropológico que a maioria de nós não domina, passa a ser um termo pejorativo usado para intimidar o indígena de ampliar seus conhecimentos e de fazer uso de objetos que não sejam de sua cultura; sobre tutela, continua sendo um elemento de artimanha acrescida da expressão contemporânea.

Pensando no que li sobre processos de formação de Estado e tentando refletir sobre os desafios colocados a cada tempo e no momento presente, vou destacar algumas ideias para tentar apontar as relações assimétricas em que estão inseridos os povos indígenas e que se constituíram juntamente com o Estado brasileiro, formando parte dessa imagem que chamei de uma "personalidade políticas do Brasil". Essas ideias, para mim, cruzam-se no tempo. Assim, farei uma leitura dos conceitos de raça, concentração de capital, modelos europeus, formação de cidades, burocracia, gestão, escola, linguagem, legislação, mentira, guerra, coerção, poder e política a partir da minha perspectiva de indígena pesquisadora.

A questão racial é uma das piores formas de segregar o ser humano, e no caso, nós povos indígenas fomos rotulados de raça inferior justamente pelos nossos modos de vida e de se relacionar com o meio ambiente que nos envolvia, ficando abaixo inclusive de grupos sociais economicamente desfavorecidos, como é notório até hoje. Pelo julgamento da raça, os povos indígenas foram condenados a perecer escravizados, assassinados, exterminados, contaminados por várias epidemias, métodos cujo objetivo era manter o poder soberano português e brasileiro e a concentração de capital pelo esbulho de terras e exploração dos bens e recursos naturais. Assim, a discriminação racial 
tem sido um dos instrumentos pelos quais se concentra capitais, se forma o Brasil e incide no poder tutelar.

Um outro modo pelo qual nós indígenas somos segregados e vivemos os efeitos dessa "personalidade política do Brasil" é o modo de agir baseado em modelos europeus de colonização/colonialidade. A sabedoria popular diz: "costume de casa vai à praça", acreditando que a "personalidade política", bem como estruturas físicas e sociais de países como Portugal, França e Holanda deixaram suas influências coloniais no Brasil sobre todos os aspectos. Outros países vieram também como colonizadores tendo o mesmo objetivo - concentrar capital; o mesmo julgamento - índio raça inferior; o mesmo tratamento - escravizar indígenas; a mesma ambição - despojar os territórios indígenas pela exploração ambiental desordenada; a mesma pregação - catequizar indígenas; a mesma atitude - exterminar indígenas; o mesmo registro - amparo pela lei; a mesma rotulação - selvagens.

A herança coercitiva europeia delineou a retenção e a concentração de poder, a política e sua legislação, em que os operadores do Estado brasileiro em suas instâncias recorrem ao uso da coerção para manter os indígenas sem regularização territorial. A pacificação tem sido um recurso habitual para fazer avançar as frentes de expansão. Nisso a formação de cidades brasileiras foi parte essencial. Os indígenas? Estavam lá, aliás, estávamos e estamos.

A expansão territorial nacional destruiu aldeamentos e construiu vilas e cidades sob o mesmo paradigma da chegada de outros europeus com impacto e ação locais (praticamente com as mesmas linhas de pensamento e ações). Como "cidadãos" indígenas, uma vez que aqueles "não eram mais" indígenas, as mudanças geográficas fluíam à revelia dos autóctones que nada podiam fazer, servindo ainda como mão-de-obra barata, ou seja, escravos, soldados, vassalos.

Para manter um nível mínimo de civilidade e poder atuar, foram necessários processos de transformação dos modos de ser indígenas - em diferentes momentos da história, fomos vítimas da catequização, da educação moral, cívica e integracionista atuando como formadora de indivíduos para servir ao Estado brasileiro, sobretudo nas guerras e também como produtores para o consumo local, nas melhorias urbanas etc. 
No alastramento da empresa colonizadora nós indígenas tivemos de aprender a lidar com a burocracia dos brancos, e mais recentemente com o funcionalismo público, cujas atribuições, geralmente regulamentados por lei, demandam na prática recursos financeiros e humanos em que questões indígenas e ambientais têm resolutivas muito mais espaçadas, em razão da concentração de capital.

Em tempos mais recentes, a burocracia - essa face algumas vezes mais, algumas vezes menos presente na vida cotidiana dos indígenas, e sob a qual acho que mais nos atemos ao imaginar uma "personalidade política do Brasil", é um mediador essencial no acesso a políticas públicas, projetos e mesmo à regularização territorial, agindo como um coletivo funcional que implementa as ações de Estado que, muitas vezes, não oferece as condições para tal.

O que nós indígenas vemos é que para além da falta de recursos financeiros, o que falta é o sentimento de "querer fazer" naqueles servidores que alimentam a ideia de submissão e de dizimação dos povos indígenas (no caso do SPI, por exemplo, como mostra o Relatório Figueiredo); que é frequente o uso da mentira e da omissão como meios de impossibilitar que os povos indígenas tenham seus territórios, contraditoriamente, com a viabilização de formas de explorar o meio ambiente; e o repasse de informações incompletas sobre como obter os mecanismos necessários sobre tais políticas públicas e projetos. Assim funciona a face mais direta da "personalidade política" do Brasil na nossa experiência!

A administração e a governança se dão a partir de normativas legais. Entretanto, a "gestão da raça indígena" tem uma história de existência e resistência contra essa "personalidade política", essa relação, na formação do Brasil. Tivemos a difícil missão de amansar, domesticar, catequizar e civilizar nossos semelhantes, cabendo ao Estado brasileiro de alguma forma, nos amparar até que estivéssemos todos integrados à comunhão nacional, ou que morrêssemos à nossa própria sorte. Ainda assim, a gestão coercitiva está na premissa da pacificação e da tutela como controle social dos povos indígenas.

Em todos esses processos que conformam a imagem que nós temos do que seja o Estado no Brasil, a escola foi e continua sendo o 
primeiro e principal espaço e instrumento estatal com o objetivo de formar um banco de recursos humanos domesticados (dos corpos, das mentes, da escrita e da oralidade) para o Estado, segregando grupos indígenas não apenas por uma questão biológica racial, mas também econômica. Tudo é em função do Estado, ou melhor, dos interesses que predominam e fazem o que seja a ação concreta da administração a cada momento do tempo.

A escola voltada aos povos indígenas passou por várias regências estatais: a princípio era atribuição do SPI/FUNAI; a partir da década de 1970, da FUNAl; em meados dos anos 1990, passa a ser do Ministério da Educação (MEC), daí, ascende à mudança administrativa que era dos municípios para o estado e a gestão aos próprios indígenas, o que não significa que a proposta de educação específica e diferenciada venceu o projeto de estratificação social, porque o Estado se impõe pleno e soberano de diferentes maneiras. Mesmo assim, as escolas indígenas têm primado pela regularização dos seus respectivos territórios ancestrais e pela preservação da natureza.

Em razão da escola, me reporto a mais um elemento de discriminação que vem a ser a construção da linguagem tida como a correta, o que vem sendo feito desde o período colonial, quando isso foi muito mais difícil pelo desconhecimento das línguas indígenas. A linguagem, como concentração de capital da informação, é intensamente usada como subterfúgio arguto para cimentar a soberania do Estado. Entre as várias formas de linguagem, um exemplo é a ortografia, um elemento ricamente ilustrado na linguagem jurídica para confundir quem não é da área, por exemplo. Mas a linguagem, não exatamente a língua, é também objeto da relação entre o Estado brasileiro e os povos indígenas no que tange à comunicação entre ambos quanto aos seus interesses, pois nem sempre a mesma palavra tem o mesmo significado podendo, entretanto, intensificar algum conflito ou, quem sabe, promover uma conciliação.

Mas, se tudo isso é possível e se nós formamos essa ideia tão abrangente do Estado, essa "personalidade política", se deu em larga medida pelo exercício aberto da violência, que começa com as guerras em suas múltiplas formas. Não vem ao caso narrar todas as guer- 
ras ocorridas no Brasil, mas, perceber a pertinência dessas conflagrações como unidade desses processos de concentração de poder que implica em destacar que nelas a presença indígena foi constante, mesmo que esse fato tenha sido em parte negado, ficando apenas nas histórias orais passadas de geração em geração sobre como foram as guerras nas primeiras relações de contato com o Estado brasileiro. Nesse sentido, trata-se também da história da guerra das raças estratificadas e subjugadas, reguladas por lei e impedidas de regressarem ao seu território de origem, quiçá, ter a possibilidade de reivindicá-los em razão das "guerras justas" regulamentadas a partir do Regimento de Tomé de Souza, que permitia de igual modo, a escravização de índios e a apropriação de suas terras ${ }^{41}$.

Visto dessa forma, a outra-história - a nossa, povos indígenas - quer mostrar é que o poder, os poderosos e as leis esconderam que não nasceram no acaso ${ }^{42}$, mas sim na injustiça das guerras. Essa outra-história mostra que a lei é ambígua, que os poderosos mascaram os fatos e sua real maneira de agir, que o poder ilude, que o coronelismo é soberbo, e que historiadores podem mentir. Será, portanto, uma devolução da astúcia e da reapropriação de um saber indígena negligenciado.

Quero voltar ao papel que tem, para nós indígenas, o que vemos como uma "personalidade política" do Brasil e ganha respaldo na legislação. Mais uma vez insisto que a luta pelo território e o meio ambiente não começou pelas leis, mas as leis sempre foram mecanismos do Estado brasileiro de induzir um pensamento sobre regras mantenedoras da ordem, do direito, do dever e da justiça para o bom convívio social, econômico e político, promovendo a igualdade de direitos ao eliminar o elemento pejorativo da biologia racial.

A lei limita e comanda a vida dos povos indígenas há mais de cinco séculos, regulamentando a espoliação dos territórios, o extrativismo abusivo da natureza, as violências diretas e simbólicas. Mas também há normativas sobre disposições contrárias, o problema é que sua efetivi-

41 Pacheco de Oliveira \& Freire, 2006, p. 209.

42 Pacheco de Oliveira, 2016, pp. 46-47. 
dade precisa superar todos esses elementos que constituem a imagem de um Estado brasileiro que temos e que tem efeitos nas nossas vidas.

Como parte do Estado, a legislação também não é estática, e pode sofrer mudanças na perspectiva da soberania e do poder das forças em luta que o compõem, dos interlocutores da administração pública sobre as regras e regimes que ela mesma cria e recria a partir de prorrogativas que ela mesma elabora e reelabora a contento dos objetivos coercitivos dos que têm o controle da máquina pública, sobretudo, para o domínio dos povos indígenas, de seus territórios e da exploração econômica dos bens e recursos naturais.

Ora, quando, em certo momento, essas forças representadas e controlando setores do Estado - e que para nós parecem ser toda a burocracia, assumindo essa máscara quase mítica que estou chamando de "personalidade política" - tentam desconstruir um direito fundamental voltado aos povos indígenas, isto é, desfazer por Decreto, Medida Provisória, Projeto de Lei ou Proposta de Emenda Constitucional o que "o Estado" fizera por algum desses meios, suscita imediatamente a revolta de lideranças indígenas que têm compromisso com o tema discutido, bem como mobiliza os povos indígenas num movimento para manutenção de direitos.

Acho que posso resumir que o que eu chamo de personalidade política do Brasil, pensando em povos indígenas, foi calcada no preconceito; pensando no meio ambiente, no esbulho. Não serei arbitrária em generalizar. Existe um paradoxo na relação entre povos indígenas e o Estado brasileiro, que enquanto tal reflete na relação assimétrica que foi cimentada inclusive por normas legais, as quais foram incisivas sobre regularização territorial como é sabido. Ao mesmo tempo que imaginamos que dessa personalidade política nossos direitos sejam reconhecidos, executados e protegidos, em função dessa personalidade pouco se fez e se faz, daí porque é dúbia. Então, quando uso a expressão personalidade política, estou restringindo a características comportamentais que construíram o caráter estatal sobre a gestão de demandas indígenas e do meio ambiente.

Ao longo da história do Brasil, da mesma maneira em que ficou estereotipada a imagem do índio, também ficou a imagem dos de- 
tentores do poder e desse aparato político estatal, parecendo estar imune às agonias dos povos indígenas que continuam dando a vida pelo direito ao território e, simultaneamente, ao meio ambiente na percepção de um direito consuetudinário dos povos originários. Então, as constituições de normas brasileiras se deram por uma combinação de sujeitos articulados em se manter no poder, em concentrar capitais, em escravizar indígenas, em edificar cidades, em formar cidadãos que não os questionem, em racionalizar direitos sociais, em criar políticas que vinham mais ao encontro do extermínio que para a proteção propriamente dita, como o Decreto de Emancipação dos Índios, a Lei de Segurança Nacional e o projeto de Maurício Rangel Reis pela tentativa de abolir os povos indígenas com o projeto de desindianização, proposto no período da ditadura militar, o qual foi trazido pelo Relatório da Comissão Nacional da Verdade, Volume II, Texto 5, em 2014:

A política indigenista a partir de 1969 inova também ao querer apressar o que entende como uma desindianização. Incomodada pela tradição jurídica do Brasil de respeito às terras indígenas, a tentativa de solução que ela adota é de abolir por canetada os detentores desses direitos à terra. Desde o Código Civil de 1916, os índios eram protegidos em seus negócios pelo instituto da capacidade relativa (assim como menores de idade entre 16 e 21 anos). O Estatuto do Índio de 1973 coloca a integração dos índios, entendida como assimilação cultural, como o propósito da política indigenista. O Ministro do Interior, Rangel Reis, declarara à CPI da Funai em 1977 que o "objetivo permanente da política indigenista é a atração, o convívio, a integração e a futura emancipação". É esse mesmo ministro quem, em 1978, tentará decretar a emancipação da tutela de boa parte dos índios, a pretexto de que eles já estão "integrados". Vários dirigentes da Funai nessa época insistem em aplicar "critérios de indianidade" para descaracterizar os sujeitos de direitos. O protesto maciço da sociedade civil em 1978 acaba por retirar esse expediente da pauta do governo. Mas não há dúvida de que a política de assimilação cultural preconizada pelo desenvolvimentismo do Estado se caracteriza como um programa de etnocídio. (BRASIL, CNV, 2014, p. 231). 
Não obstante, pelas narrativas históricas, a ditadura militar recuperou toda violência colonial contra os povos indígenas e endossou isso que estou chamando de personalidade política. Foram 21 anos de um severo regime político (1964 a 1985). A maior ironia desse período é que o SPI, criado em 1910/1918 como agência estatal para prestar assistência a todos os indígenas, respeitar suas terras, culturas e tradições, agiu contrariamente a esses propósitos, asseverando o extermínio de inúmeras etnias indígenas.

Devo lembrar que, segundo Pacheco de Oliveira \& Freire (2006: 232), o SPI passou a ser considerado de "interesse militar", podendo ser orientado por interesses de "segurança nacional", conforme o Decreto $n^{\circ} 43.091$ de 22 de janeiro de 1958:

Art. $1^{\circ}$ São acrescidas às funções enumeradas no art. $1^{\circ}$ do Decreto $n^{\circ} 30.955$, de 7 de junho de 1952, as de Diretor do Serviço de Proteção aos Índios e de Diretor do Serviço de Meteorologia, do Ministério da Agricultura, quando exercidas por Oficial de qualquer das três Forças Armadas. (Decreto n 43.091 de 22 de janeiro de 1958. Juscelino Kubistchek, Presidente da República).

Destaca-se que a partir da década de 1940, face ao fim da II ${ }^{a}$ Guerra Mundial (Carta das Nações Unidas/1945), houve o reconhecimento universal de direitos humanos, fundamentais, sociais, de gênero e geração que influenciariam no futuro reconhecimento dos povos indígenas e tribais pela Organização Internacional do Trabalho em 1957, por sua Convenção $n^{\circ} 107^{43}$. A partir desse marco e dos princípios estabelecidos, outros instrumentos internacionais reforçam a mesma premissa confirmando a essência da garantia desses direitos.

Todavia, existiu uma via de controle e acesso aos direitos internacionais dos indígenas de que o Brasil é signatário: a tutela. Mais de três décadas depois do fim da ditadura, de inúmeros marcos legais

43 "Convenção n 107 da OIT, de 05 de junho de 1957, concernente à proteção e integração das populações indígenas e outras populações tribais e semitribais de países independentes." Disponível em: <http://www.mpf.mp.br/atuacao-tematica/ccr6/documentos-e-publicacoes/ legislacao/legislacao-docs/convencoes-internacionais/conv_intern_02.pdf/view>. Acesso em 08 jan. 2018. 
nacionais e internacionais assinados pelo Brasil, vemos os fantasmas dos atos violentos que lembram a chegada dos europeus incorporando no momento presente e evocando tormentas sob o mesmo objetivo, julgamento, tratamento, ambição, pregação, atitudes, e rotulação no cotidiano da luta dos povos indígenas pelo território e o meio ambiente, sempre apelando à lei para sua efetivação.

Em certa medida, há muita contradição no que vi sobre a história do Brasil, independentemente de suas (re)formulações ao longo desses cinco séculos. Certamente, essas reformulações se deram para assentar uma autoimagem do Brasil como país acolhedor, pluriétnico, multicultural, laico, de uma riqueza biodiversa e com uma Constituição Federal avançada. Na época em que estudei na aldeia, a história enaltecia fatos históricos como o descobrimento do Brasil (o início de uma invasão) e os heróis que fizeram brilhar essas histórias, além de ter sido influenciada para acreditar que a FUNAI era uma mãe benevolente para com seus filhos órfãos (os índios), e os esforços para nos integrar à comunhão nacional faziam parte desses cuidados de mãe. Infelizmente, ainda tem muito autóctone que até hoje chama "mamãe FUNAI" e de certa forma se acomodou em buscar seus direitos, porque espera e acredita que "a mamãe" vai fazer!

Atualmente, existe uma série de normativas que limitam os atos genocidas do Estado brasileiro sobre os povos indígenas, mas que eficazmente não funcionam como proibição, e as violações acontecem a todo tempo, como disse acima. Só para se ter uma ideia sobre esse tema, na Assembleia Geral das Nações Unidas de 09 de dezembro de 1948, foi acordada a Convenção para Prevenção e Repressão do Crime de Genocídio, a qual entrou em vigor na ordem internacional em 12 de janeiro de 1951. No Brasil, o Congresso Nacional aprovou a Convenção pelo Decreto Legislativo n 2 de 11 de abril de 1951 e Getúlio Vargas promulgou tal Convenção por meio do Decreto $n^{\circ} 30.822$, de 06 de maio de 1952. Em 01 de outubro de 1956 pela lei $n^{\circ} 2.889$, Juscelino Kubitschek define e pune o crime de genocídio. A CF/88 trata o tema como crime hediondo no art. $5^{\circ}$, XLIII.

Essa narrativa histórica deve ser contada pelo direito que nos é conferido como principal personagem da história do Brasil. De uma luta 
que não cessou e que para além dos conflitos físicos, a luta é também para manutenção dos nossos direitos quanto ao território e à nossa natureza sagrada.

\section{CONCLUSÃO}

Minha ideia de conclusão não é redundar, mas complementar o que já foi exposto acima. Eu parto de uma perspectiva temporal que nada se compara ao tempo de luta dos povos indígenas pelo território e pelo meio ambiente, sobretudo a partir das leis. Dessa viagem no tempo que fiz, houve momentos em que sentia que não tinha saído do canto pensando nessa relação. Se eu fosse transformar essa ideia numa imagem de relógio, diria que o ponteiro do segundo são ações anti-indígena, é mais rápido; o do minuto, o tríplice poder (executivo, legislativo e judiciário), que compassa cada momento; o da hora a lei, que marca cada momento. $E$ nós indígenas somos os números: não faz diferença se não estivermos, os ponteiros irão girar do mesmo jeito, principalmente do minuto e da hora.

A genealogia parte da luta pelo território e pelo meio ambiente que desde a colonização, "Brasil" (que não é uma pessoa) e "povos indígenas" (que não são um coletivo homogêneo) são personagens dessa contenda pela terra e pelos bens e recursos naturais. De um lado, os poderes coercitivos - o Estado brasileiro. Do outro, os poderes de resistência - os povos indígenas. Aparentemente entre ambos, a lei - ambígua, no sentido de que por ser um dispositivo do Estado para validar sua soberania, não existe nenhuma garantia de sua eficácia ao recorrermos à lei. Essa natural desconfiança se justifica pela história do efeito legal, (jurídico e prático) do porquê as leis surgiram pensando em povos indígenas, então, fica a pergunta: será que dessa vez a lei, ou o Estado, vai concretizar nossos direitos? O fato é que, nós indígenas, precisamos nos valer das leis para buscar um acordo com o Estado, até mesmo para impedir que os direitos que conquistamos não sejam revogados. Inclusive como meio de revalidarmos nossa autonomia e extirpar a tutela contemporânea. Notadamente o Estado não é uma unidade, mas sua gestão está para quem a faz, e não para quem serve. 
Conquanto, a história da legislação pertinente ao meio ambiente aborda como o Estado brasileiro tem mantido o domínio sobre os bens e recursos naturais, bem como dos minerais e dos recursos hídricos. O exposto no art. 225, caput, da Constituição Federal de 1988, "impõe ao poder público e à coletividade o dever de cuidá-lo para às presentes e futuras gerações", cabendo a cada pessoa defender e preservar os espaços que ocupam, que frequentam, que transitam. No entanto, para que haja esse engajamento, é fundamentalmente necessário que absolutamente todos assumam esse compromisso - socioespacial - e desencadeiem ações de respeito para o uso, extração, manutenção, preservação e conservação visando à qualidade salutar das naturezas dos lugares para além do ecológico, importando dizer que gestão ambiental não se limita a plantas, animais e biomas, mas se reflete pela ação coletiva humana em todas as ambiências que retroalimentam um bioma ao outro, consequentemente à sadia qualidade de vida no planeta.

A compilação da pesquisa bibliográfica e técnica aqui apresentada não é apenas um ajuntamento de fontes, é um passo para construirmos a outra-história da relação do Estado brasileiro com os povos indígenas e o meio ambiente a partir das leis, nacionais e internacionais, um modo de caminharmos para nos livrarmos da crença em uma "personalidade política" única e coesa, como se o Estado fosse uma coisa só, homogênea, dotada de intenções, como um indivíduo ou entidade dotado/a de juízo consciente. A luta por direitos, sejam eles indígenas, sejam em prol do meio ambiente ecologicamente equilibrado, para os povos indígenas é uma única luta, continua tal qual começou, de modo que, mesmo o Estado brasileiro reconhecendo em leis, não significa seu fiel cumprimento.

O que não mudou no decorrer do tempo, é que a segregação da raça indígena, foi colocada tão abaixo de outras raças que nem mesmo com a ratificação da Convenção Internacional sobre Eliminação de todas as formas de Discriminação Racial (1965), na prática, incorporou os povos indígenas, mantendo-os escravos da própria lógica social, sem direito ao território e ao meio ambiente. De igual forma, a concentração de capital continua a limitar a regularização territorial em razão da exploração econômica sobre bens e recursos naturais, seguindo modelos europeus e até mesmo para formação, manutenção e cresci- 
mento de cidades. Em certa medida, isso é o que fomenta propostas de mudanças nos direitos dos povos indígenas e do meio ambiente.

A burocracia, na perspectiva dos trâmites regulatórios para o território, não aplica o Decreto $n^{\circ} 1.775 / 96$, tampouco fez cumprir a ordem expressa na Lei $n^{\circ}$ 6.001/73 e na Constituição de 1988 sobre o prazo de cinco anos para regularização territorial indígena, nem mesmo as da época, desempenhando uma má gestão e acirrando a luta pela terra.

As escolas indígenas, no discurso pelo específico e diferenciado, adotam uma linguagem de valorização destes espaços, assim como a saúde específica que valoriza os saberes da Mãe Natureza. Por isso a guerra não cessou. Silenciosa ou visual, é uma guerra nas academias pela autodeterminação indígena reconhecida por lei já no art. $4^{\circ}$, III da Constituição Federal de 1988; é uma guerra oral na linguagem de negociação que recorre as normativas legais em defesa desses direitos; é uma guerra civil com a sociedade envolvente para poder usufruir dos mesmos espaços e direitos; e é uma guerra física na luta pelo território e o meio ambiente ecologicamente equilibrado.

E por várias razões os elementos que destaquei da formação do Estado brasileiro, enseja o que para nós e para muitos parece uma "personalidade política do Brasil", vieram a legalizar e legitimar aquelas formas pelas quais se discriminou e se discrimina os povos indígenas (frentes de expansão, fricção interétnica, pacificação, catequização, aculturação e tutela), com o intuito de destravar qualquer barreira ao avanço econômico e político do país pelo completo domínio do território nacional e de toda biodiversidade, incluindo o ser humano, sem restringir-se a nós, indígenas. A relação simbiótica e espiritual com a natureza é o que transfigura na essência do ser indígena, indubitavelmente, a legislação reconhecida pelo Estado brasileiro como sistema universal, precisa saber mais além da lógica do visível.

Pôr à vista a luta pelo território e pelo meio ambiente ecologicamente equilibrado através das leis é propor aos povos indígenas uma versão da história sobre os marcos legais que reconhecem nossos direitos que tiveram tempos, razões e motivos distintos. Tentei aqui propor também como o direito se constitui, como e quando ele funciona e 
porque não funciona, elevando a importância de saber quantos, quais são e onde estão esses direitos ${ }^{44}$, robustecendo uma linguagem técnica e política para lutar e defender o território e o meio ambiente ecologicamente equilibrado a partir das leis dos homens e da natureza.

Todas as ferramentas para resolutiva deste conflito estão postas: povos indígenas, Estado brasileiro, legislações, terra, interesses, perspectivas, passado, presente e futuro. A luta pelo território e pelo meio ambiente está longe de acabar, mas nós indígenas vamos continuar resistindo, recorrendo sim o que dispõe a lei para demarcação, homologação e desintrusão de nossas terras. A única certeza que ouso dizer é que nós, povos indígenas, precisamos estar sabedores dessas regulamentações do branco, não porque a temos como soberana do jeito que nos é imposta, mas porque se trata de usar - também - os mesmos instrumentos com que o inimigo nos atinge. Se trata, sobretudo, de apreender estratégias simultâneas e articuladas em defesa e na luta pelo território e pelo meio ambiente, desviando-nos de investidas negativas em razão de uma personalidade política dúbia que usa a tutela contemporânea em favor próprio.

... Avançaremos!!

\section{REFERÊNCIAS BIBLIOGRÁFICAS}

ARAÚJO, Ana Valéria. In: Povos Indígenas a Lei dos "Brancos": o direito à diferença / Ana Valéria Araújo et alii - Brasília: Ministério da Educação, Secretaria de Educação Continuada, Alfabetização e Diversidade; LACED/Museu Nacional, 2006.

BORGES, Luís Antônio Coimbra; REZENDE, José Luiz Pereira \& PEREIRA, José Aldo Alves. "Evolução da Legislação Ambiental no Brasil”. Revista em Agronegócios e Meio Ambiente, v.2, n.3, p. 447466, set./dez. 2009 - ISSN 1981-9951.

44 O levantamento completo encontra-se nos anexos desse artigo. 
BOURDIEU, Pierre. Espíritos de Estado. Gênese e estrutura do campo burocrático. In: Razões práticas: sobre a teoria da ação. Campinas: Papirus, 1996, pp 91-136.

BRASIL. Comissão Nacional da Verdade: "Violação de Direitos Humanos dos Povos Indígenas". Texto 5. Brasília, CNV, 2014.

BRASIL. Constituição da República Federativa do Brasil, de 05 de outubro de 1988.

BRASIL. Constituição Federal Republicana, publicada em 24 de fevereiro de 1891. Disponível em: <http://www.planalto.gov.br/ccivil_03/ constituicao/constituicao91.htm>. Acesso em 16 jan. 2018.

BRASIL. Constituição Política do Império do Brasil, promulgada em 25 de março de 1824. Disponível em: <http://www.planalto.gov.br/ ccivil_03/constituicao/constituicao24.htm>. Acesso em 16 jan. 2018.

BRASIL. Decreto Legislativo $\mathrm{n}^{\circ} 2$ de 11 de abril de 1951. Aprova o texto da Convenção de Prevenção e Repressão do crime de genocídio, firmada em Paris em dezembro de 1948, pelo Brasil e outros países, durante a Terceira Sessão da Assembleia Geral das Nações Unidas.

BRASIL. Decreto $n^{\circ} 1.775$, de 08 de janeiro de 1996. Dispõe sobre o procedimento administrativo de demarcação das terras indígenas e dá outras providências.

BRASIL. Decreto $n^{\circ} 22$ de 04 de fevereiro de 1991. Dispõe sobre o processo administrativo de demarcação das terras indígenas e dá outras providências. Disponível em: <http://www.planalto.gov.br/ ccivil_03/decreto/1990-1994/D0022.htm>. Acesso em 11 jan. 2018.

BRASIL. Decreto $n^{\circ}$ 30.822, de 06 de maio de 1952. Promulga a Convenção para a Prevenção e a Repressão do Crime de Genocídio, concluída em Paris, a 11 de dezembro de 1948, por ocasião da III Sessão da Assembleia Geral das Nações Unidas.

BRASIL. Decreto $n^{\circ} 608$, de 20 de julho de 1992. Altera o Decreto $n^{\circ} 22$, de 04 de fevereiro de 1991, que dispõe sobre o processo de demarcação 
das terras indígenas. Disponível em: <http://www.planalto.gov.br/ccivil_03/ decreto/1990-1994/D0608.htm>. Acesso em 11 jan. 1018.

BRASIL. Decreto $n^{\circ} 88.118$ de 23 de fevereiro de 1983. Dispõe sobre o processo administrativo de demarcação de terras indígenas e dá outras providências. Acesso em 11 jan. 2018.

BRASIL. Decreto n ${ }^{\circ} 94.945$ de 23 de setembro de 1987. Dispõe sobre o processo administrativo de demarcação de terras indígenas e dá outras providências. Disponível em: <http://www.planalto.gov.br/ccivil_03/ decreto/1980-1989/1985-1987/D94945.htm>. Acesso em 11 jan. 2018.

BRASIL. Emenda Constitucional n 3, de 03 de setembro de 1926. Dispõe sobre Emendas à Constituição Federal de 1891. Disponível em: <http://www.planalto.gov.br/ccivil_03/constituicao/emendas/emc_ anterior1988/emc\%20de\%203.9.26.htm>. Acesso em 16 jan. 2018.

BRASIL. Lei $n^{\circ} 10.406$, de 10 de janeiro de 2002. Novo Código Civil Brasileiro.

BRASIL. Lei $n^{\circ}$ 13.146, de 06 de julho de 2015. Institui a Lei Brasileira de Inclusão da Pessoa com Deficiência - Estatuto da Pessoa com Deficiência.

BRASIL. Lei $n^{\circ} 2.889$, de 01 de outubro de 1956. Define e pune o crime de genocídio.

BRASIL. Lei n 3.071, de 01 de janeiro de 1916. Código Civil Brasileiro. BRASIL. Lei $n^{\circ}$ 6.001, de 19 de dezembro de 1973. Dispõe sobre o Estatuto Índio.

BRASIL. Lei $n^{\circ} 601$ de 18 de setembro de 1850. Lei de Terras. Disponível em: <https://pt.wikipedia.org/wiki/Lei_de_Terras; https:// pt.wikipedia.org/wiki/Independ\%C3\%AAncia_do_Brasil). Acesso em 16 nov. 2017.

CARDOSO DE OLIVEIRA, Luis Roberto. "Moral e ética”. In:Antropologia e direito: temas antropológicos para estudos jurídicos. Antonio Carlos 
de Souza Lima (Coord.). Brasília/Rio de Janeiro/Blumenau: Associação Brasileira de Antropologia/LACED/ Nova Letra, 2012.

CARDOSO DE OLIVEIRA, Luiz Roberto; GROSSI, Mirian Pillar; LINS RIBEIRO, Gustavo. "Apresentação". In: Antropologia e direito: temas antropológicos para estudos jurídicos. Antonio Carlos de Souza Lima (Coord.). Brasília/Rio de Janeiro/Blumenau: Associação Brasileira de Antropologia/LACED/Nova Letra, 2012.

CARNEIRO DA CUNHA, Manuela. 2009. "Cultura" e cultura: conhecimentos tradicionais e direitos intelectuais". In: M. Carneiro da Cunha. Cultura com aspas. São Paulo: Cosac Naify. Pp. 311-372.

CASTILHO, Ela Wiecko V. de. "Introdução". In: Antropologia e direito: temas antropológicos para estudos jurídicos. Antonio Carlos de Souza Lima (Coord.). Brasília/ Rio de Janeiro/Blumenau: Associação Brasileira de Antropologia/LACED/Nova Letra, 2012.

Convenção Internacional sobre Eliminação de todas as formas de Discriminação Racial, 1965.

Convenção $n^{\circ} 107$ da OIT, de 05 de junho de 1957, Concernente à proteção e integração das populações indígenas e outras populações tribais e semitribais de países independentes." Disponível em: <http:// www.mpf.mp.br/atuacao-tematica/ccr6/documentos-e-publicacoes/ legislacao/legislacao-docs/convencoes-internacionais/conv_ intern_02.pdf/view>. Acesso em 08 jan. 2018.

Convenção para Prevenção e Repressão do Crime de Genocídio, 1948.

CORREA, Jader Figueiredo de. "Relatório Figueiredo" de 03 de novembro de 1967.

Cronologia da legislação ambiental. Disponível em: <https://stj.jusbrasil. com.br/noticias/2219914/linha-do-tempo-um-breve-resumo-daevolucao-da-legislacao-ambiental-no-brasil>. Acesso em 16 nov. 2017.

ELIAS, Norbert. "Processos de formação de Estados e construção de nações”. In: Escritos \& ensaios; 1: Estado, processo, opinião pública. 
Organização e apresentação Federico Neiburg e Leopoldo Waizbort. Rio de Janeiro: Jorge Zahar Ed, 2006 (1972), pp.153-165.

FOUCAULT, Michel. Em defesa da sociedade: curso no Collège de France (1975-1976). São Paulo: Martins Fontes, 1999, pp. 75-98.

Segurança, território, população: curso dado no Collège de France (1977-1978). São Paulo: Martins Fontes, 2008.

Vigiar e punir: nascimento da prisão. Petrópolis, Vozes, (1978) 1999.

FRY, Peter. "Diferenças, desigualdades e discriminação". In: Antropologia e direito: temas antropológicos para estudos jurídicos / coordenação geral [de] Antonio Carlos de Souza Lima - Brasília/Rio de Janeiro/Blumenau: Associação Brasileira de Antropologia/ LACED/ Nova Letra, 2012. p. 227-233.

GELLNER, Ernest, (1926). Antropologia e política: revoluções no bosque sagrado. Rio de Janeiro: Jorge Zahar Ed., 1997.

JOCA, Martha Priscylla Monteiro J. Martins. "Direito(s) e(m) Movimento(s): Assessoria Jurídica Popular a Movimentos Populares Organizados em torno do Direito à Terra e ao Território em Meio Rural no Ceará". Dissertação de Mestrado apresentada ao Programa de Pós-Graduação da Faculdade de Direito da Universidade Federal do Ceará para obtenção do grau de Mestre em Direito. Universidade Federal do Ceará - UFC, 2011.

KANT DE LIMA, Roberto. "Antropologia jurídica". In: Antropologia e direito: temas antropológicos para estudos jurídicos. Antonio Carlos de Souza Lima (Coord.). Brasília/Rio de Janeiro/Blumenau: Associação Brasileira de Antropologia/ LACED/Nova Letra, 2012.

Direitos civis e direitos humanos: uma tradição judiciária prérepublicana?. São Paulo em Perspectiva, 18(1): 49-59, 2004.

OIT. Convenção 169, da Organização Internacional do Trabalho para Povos Tribais, $x x x x$. 
PACHECO DE OLIVEIRA, João. "Pacificação e tutela militar na gestão de populações e territórios”. Mana, 20(1), 2014.

"Perícia Antropológica". In: Antropologia e direito: temas antropológicos para estudos jurídicos. Antonio Carlos de Souza Lima (Coord.). Brasília/Rio de Janeiro/Blumenau: Associação Brasileira de Antropologia/LACED/ Nova Letra, 2012. Pp. 125-146.

"Sem a tutela, uma nova moldura de nação". In Souza Lima, Antonio Carlos (org) Tutela: Formação de Estado e tradições de gestão no Brasil. Rio de Janeiro: E-papers, 2014.

O nascimento do Brasil e outros ensaios: "pacificação", regime tutelar e formação de alteridades. João Pacheco de Oliveira. Rio de Janeiro: Contra Capa, 2016.

PACHECO DE OLIVEIRA, João; ALMEIDA, Alfredo Wagner Berno de. "Demarcação e reafirmação étnica: um ensaio sobre a FUNAl". In Indigenismo e territorialização (p.69 a 123). Fundação Ford. Rio de Janeiro, 1998.

PACHECO DE OLIVEIRA, João; FREIRE, Carlos Augusto da Rocha. A presença Indígena na Formação do Brasil. Brasília: Ministério da Educação, Secretaria de Educação Continuada, Alfabetização e Diversidade; LACED/Museu Nacional, 2006.

Reconhecimento das etnias indígenas no Ceará. Disponível em: $<$ http://www.ecodebate.com.br/2008/12/22/o-reconhecimento-dasetnias-indigenas-no-ceara-passa-pela-demarcacao-de-suas-terras/>; acesso em 16 nov. 2017.

SAMPAIO, Patrícia Melo. "Fronteiras da liberdade. Tutela indígena no Diretório Pombalino e na Carta Régia de 1798”. In Souza Lima, Antonio Carlos (org). Tutela: Formação de Estado e tradições de gestão no Brasil. Rio de Janeiro: E-papers, 2014.

SEYFERTH, Giralda. "Minoria". In: Antropologia e direito: temas antropológicos para estudos jurídicos / coordenação geral [de] Antonio 
Carlos de Souza Lima - Brasília/Rio de Janeiro/Blumenau: Associação Brasileira de Antropologia/ LACED/Nova Letra, 2012. pp. 234-239.

In: A invenção da raça e o poder discricionário dos estereótipos. Museu Nacional, UFRJ. Anuário Antropológico/93. Rio de Janeiro: Tempo Brasileiro, 1995. pp. 175-203.

SOUZA LIMA, Antonio Carlos de. "A pacificação como prática de poder no contexto da criação do Serviço de Proteção aos Índios". In: Um Grande Cerco de Paz: Poder tutelar, indianidade e formação do Estado no Brasil. Petrópolis, Vozes, 2009.

"Notas sobre a organização". In: Antropologia e direito: temas antropológicos para estudos jurídicos. Antonio Carlos de Souza Lima (Coord.). Brasília/Rio de Janeiro/Blumenau: Associação Brasileira de Antropologia/ LACED/Nova Letra, 2012.

"O exercício da tutela sobre os povos indígenas no Brasil: um itinerário de pesquisa e algumas considerações sobre as políticas indigenistas no Brasil contemporâneo". In Souza Lima, Antonio Carlos de (org). Tutela: Formação de Estado e tradições de gestão no Brasil. Rio de Janeiro: E-papers, 2014.

"Sobre tutela e participação: povos indígenas e formas de governo no Brasil, séculos XX/XXI”. Mana, 21(2) 425-457, 2015.

Apresentação. Dossiê Fazendo Estado. O estudo antropológico das ações governamentais como parte dos processos de formação estatal. Revista de Antropologia (USP. Impresso), v. 55, 2012. pp. 559-564.

Povos indígenas no Brasil contemporâneo: De tutelados a "organizados"? LACED. 2010. Pp. 15-50. Disponível em: <http://laced. etc.br/site/arquivos/03-Povos-II.pdf>. Acesso em 16 jan. 2018.

Prefácio. In: Povos Indígenas a Lei dos "Brancos": o direito à diferença / Ana Valéria Araújo et alii - Brasília: Ministério da Educação, Secretaria de Educação Continuada, Alfabetização e Diversidade; LACED/Museu Nacional, 2006. 
Sobre Indigenismo, Autoritarismo e Nacionalidade: Considerações sobre a constituição do discurso e da prática da proteção fraternal no Brasil. In: João Pacheco de Oliveira. (Org.). Sociedades Indígenas e Indigenismo no Brasil. 1ed. Rio de Janeiro/ São Paulo: UFRJ/Marco Zero, 1987, v. p. 149-214.

Um Grande Cerco de Paz: Poder tutelar, indianidade e formação do Estado no Brasil. Petrópolis, Vozes, 1995.

TEIXEIRA, Carla Costa. "Pesquisando instâncias estatais: reflexões sobre o segredo e a mentira". In Castilho, S.R.; Teixeira, C.; Souza Lima, A.C. Antropologia das Práticas de Poder: Reflexões etnográficas entre burocratas, elites e corporações. Rio de Janeiro: Contra Capa, 2014.

TEIXEIRA, Carla Costa; SOUZA LIMA, A. C. de. "A antropologia da administração e da governança no Brasil: área temática ou ponto de dispersão?". In: Duarte, Luiz Fernando Dias, coord. de área; Martins, Carlos Benedito, coord. geral. (Org.). Horizontes das ciências sociais no Brasil: antropologia. 1ed.São Paulo: ANPOCS, 2010. pp. 51-95.

TILLY, Charles. Coerção, capital e estados europeus (990-1992). São Paulo: EDUSP, 1996.

VIANNA, Adriana. "Etnografando Documentos": uma antropóloga em meio a processos judiciais". In Castilho, S.R.; Teixeira, C.; Souza Lima, A.C. Antropologia das Práticas de Poder: Reflexões etnográficas entre burocratas, elites e corporações. Rio de Janeiro: ContraCapa, 2014.

Introdução. "Direito à diferença". In: Antropologia e direito: temas antropológicos para estudos jurídicos / coordenação geral [de] Antonio Carlos de Souza Lima - Brasília/Rio de Janeiro/Blumenau: Associação Brasileira de Antropologia/ LACED/Nova Letra, 2012. pp. 202-211.

WEBER, Max. "Estruturas Sociais e Tipos de Capitalismo"; "A política como Vocação"; In: ___. Ensaios de sociologia. $3^{a}$ ed.. Rio de Janeiro: Zahar Editores, 1974. pp. 85-89; 97-153. 


\section{ANEXO 1}

\section{CRONOLOGIA SOBRE A LEGISLAÇÃO PERTINENTE AOS POVOS INDÍGENAS - 1500 A 2000:}

- Em 1511, Américo Vespúcio fundou a feitoria de Cabo Frio, ao tempo em que durante o regime de feitorias, o Regimento que regulou o comércio de pau-brasil chegou à Bahia na Nau Bretoa.

- Em 1537, o Papa Paulo III divulgou uma Bula contrária à escravização dos índios na América.

- 1549, a Carta Régia de 29 de janeiro, instituiu o Governo Geral no Brasil. O Regimento do $1^{\circ}$ governador, Tomé de Souza, recomendava "o cuidado dos índios".

- 1556, Mem de Sá foi nomeado governador geral do Brasil por Carta Régia de 23 de julho. Responsável por inúmeras violências contra os povos indígenas.

- Em 1558 a partir da Carta Régia, Mem de Sá declarou guerra contra os inimigos da Coroa portuguesa, que vinham a ser primariamente os indígenas.

- O Alvará de 03 de agosto de 1559, definia que moradores podiam negociar com índios ferramentas.

- 1562, mais de 30 mil índios e negros foram dizimados na Bahia por epidemias de varíola, ao tempo em que a Carta de Sesmarias definiu os limites as terras dos índios da aldeia do Espírito Santo.

- 1570 é promulgada a Lei contra a escravidão dos índios, excetuando-se os Aimoré. A escravização só seria possível através de "guer- 
ra justa" - Carta Régia de 20 de março de 1570 - autorizada pelo rei ou governador do Brasil.

- 1580, Carta de Sesmarias sobre a terra dos índios de São Paulo.

- 1582, através do Alvará da Coroa de 21 de agosto, índios ganharam sesmarias de terra e o direito à restituição de terras ocupadas.

- 1587, Lei de 24 de fevereiro que estabeleceu que índios do Brasil podiam ou não ser escravizados. Em 21 de agosto, é publicado o Alvará sobre índios descidos do sertão que garantiu terras para as aldeias e sesmarias para as lavouras. No dia seguinte $(22 / 08)$, foi declarada a Lei sobre a escravidão indígena, era apenas possível através de "guerra justa".

- Em 11 de novembro de 1595, é publicada a Lei que estabelecia o caso em que se podiam escravizar "gentios" no Brasil.

- 1596, o Alvará de 26 de julho estabeleceu o governo dos índios do Brasil pelos jesuítas, proibiu a escravidão indígena e reconheceu as "guerras justas".

- Em 31 de dezembro de 1601, é promulgada a Lei de abolição da escravatura indígena.

- 1606, a Provisão real de 05 de junho concedeu ampla liberdade aos índios.

- 1611, Lei de 10 de setembro que reconheceu o cativeiro de índios aprisionados em "guerras justas" ou cativos de outros índios, estabelecendo a liberdade para os demais índios.

- 1623, a Carta Régia determinava deixar nos aldeamentos 1/5 dos índios capturados em expedições de apresamento.

- 1639, a Bula Papal de 22 de abril, declarou livres os índios da América. 
- O Alvará de 10 de novembro de 1647, declarou a liberdade dos índios do Maranhão, que teriam seu trabalho remunerado.

- 1653, paulistas foram proibidos de capturar índios aldeados, só podendo escravizar índios através de "guerra justa" ou "resgate".

- 1663 pela Provisão de 12 de setembro, estabeleceu que as câmaras municipais regulamentariam as bandeiras que aprisionavam índios.

- Carta Régia de 29 de abril de 1667 dispõe sobre as condições da escravidão indígena.

- 01 de abril de 1680, Regimento das Missões do Estado do Maranhão proibindo a escravidão indígena.

- 01 de dezembro de 1686, Regimento das Missões do Estado do Maranhão e Grão-Pará garantia o direito dos índios a terra onde habitavam.

- 1687, Carta Régia que estabeleceu para as ordens religiosas as áreas de atuação missionária no Brasil.

- 28 de abril de 1688, Alvará Régio que estabelecia a escravidão de prisioneiros índios tomados em guerra defensiva.

- 25 de janeiro de 1696, Carta Régia que estabeleceu condições para a concessão da administração dos índios por moradores do Brasil.

- 1707, Carta Régia entregando aos franciscanos as missões do Baixo Amazonas.

- 1708, Carta Régia de 20 de abril, permitia o cativeiro e a venda de índios.

- 1714, a Ordem dos Mercedários estabeleceu missões no Baixo Amazonas. 
- 09 de março de 1718, a Ordem Régia estabelecia a liberdade dos índios descidos para os aldeamentos. A Coroa portuguesa voltou a aceitar a escravidão indígena.

- 1741, a Bula Papal "Immensa Pastorum" condenou a escravidão dos índios no Brasil.

- 1744, a Bula Papal de benedito XIV proibia qualquer cativeiro - secular ou eclesiástico - dos índios.

- 1750, os Sete Povos das Missões passaram a pertencer ao território português com a assinatura do Tratado de Madrid, que definiu os novos limites das possessões espanholas e portuguesas.

- 06 de junho de 1755, é publicada a Lei que extinguiu o cativeiro dos índios no Estado do Maranhão.

- 1757, o Marquês de Pombal criou o regime de Diretório dos Índios, substituindo o Regimento das Missões.

- 1758, o Alará Régio aprovou a criação do Diretório dos Índios. E em 08 de maio do mesmo ano, aboliu a escravidão indígena.

- 1759 o sistema de Capitanias Hereditárias foi extinto no Brasil.

- Em 22 de junho de 1808, foi publicado o Decreto que regulamentou a posse de sesmarias no Brasil. E no dia 05 de novembro de 1808 e 01 de abril de 1809 estabeleceram iniciativas para a civilização dos Botocudos do Paraná (Kaingang), povoando os campos gerais de Curitiba e Guarapuava.

- O Aviso de 19 de maio de 1809, ordenou o engajamento de índios Botocudos nos serviços de transporte do Arsenal de Marinha do Rio de Janeiro. Em 13 de julho do mesmo ano, a Carta Régia deu aos colonos que entraram nas terras resgatadas dos Botocudos 10 anos para cultivá-las, demarcá-las e outras providências administrativas relativas às sesmarias. 
- O Aviso de 19 de fevereiro de 1811, aprovou o estabelecimento de 03 mil colonos, com a fundação de colônias em terras desocupadas por índios "bárbaros" (Botocudos). O Decreto de 09 de julho mandou formar na Província de Missões um Regimento de Milícias Guaranis a cavalo. A Carta Régia de 05 de setembro determinava que deveriam ser tratadas com moderação e humanidade as nações indígenas de Goiás e do Pará que não cometessem hostilidades; caso contrário, deveria ser usada a força armada contra as nações Karajá, Apinayé, Xavante, Xerente e Canoeiro, intimidando-as e até destruindo-as se necessário.

- O Aviso de 27 de setembro de 1814, no interesse de que não fossem divididas as terras auríferas dos índios Croatos, ordenou que não se concedessem datas de mineração nessas terras.

- 1819 , as terras das aldeias indígenas foram declaradas inalienáveis.

- 1824, No Espírito Santo, o aldeamento dos índios do rio Doce ganhou regulamento provisório.

- A Lei de 27 de outubro de 1831, aboliu definitivamente o cativeiro e a servidão indígena no Brasil. Foram revogadas as Cartas Régias que declaravam guerra aos índios das Províncias de São Paulo e Minas Gerais.

- 1850, a Lei Eusébio de Queirós declarou a extinção do tráfico negreiro no Brasil. É promulgada a Lei 601, em 18 de setembro, conhecida como a Lei de Terras.

- Em 24 de abril de 1857, missionários tornaram-se diretores das colônias indígenas criadas nas Províncias do Paraná e do Mato Grosso.

- 1891, o Congresso Nacional promulgou a primeira Constituição da República. 
- Através do Decreto $n^{\circ}$ 8.072, de 20 de junho de 1910, é criado o Serviço de Proteção aos Índios e Localização de Trabalhadores Nacionais (SPILTN), e aprovou seu regulamento.

- O Decreto $n^{\circ} 9.214$, de 15 de dezembro de 1911, cria o novo regulamento do SPILTN.

- 1912, Manoel Miranda e Alípio Bandeira publicaram um memorial acerca da situação do índio perante a legislação antiga e a moderna.

- A Lei do Orçamento - Lei n² 2.842, de 03 de janeiro de 1914 - impôs restrições ao SPI, diminuindo a estrutura do órgão.

- Em 01 de janeiro de 1916, a Lei n 3.071 estabeleceu o Código Civil. No art. $6^{\circ}$ os "silvícolas" foram declarados "incapazes" em relação a certos atos ou à maneira de exercê-los, ficando ainda "sujeitos ao regime tutelar, estabelecido em leis e regulamentos especiais, o qual cessará à medida que se forem adaptando à civilização do país" (art. $6^{\circ}, \S$ único).

- No dia 06 de janeiro de 1918, a parte do SPILTN referente aos trabaIhadores nacionais passou para o Serviço do Povoamento do Solo, por determinação do Decreto-lei n 3.454 .

- O Decreto $n^{\circ} 4.301$, de 20 de outubro de 1927, do governo de São Paulo, reservava terras para os índios assistidos pelo SPI no município de Itanhaém.

- Pelo Ato $n^{\circ}$ 637, de 20 de junho de 1928, o governo de Pernambuco reconheceu o direito das terras (posse) aos índios e das benfeitorias aos "rendeiros". A Lei $n^{\circ} 5.484$, de 27 de junho do mesmo ano, regulamentou a situação dos índios nascidos no território nacional.

- 1929, Manoel Miranda e Alípio Bandeira publicaram artigo sobre a situação jurídica do índio no livro Colletânea indígena. 
- Pelo Decreto $n^{\circ} 19.433$, de 26 de novembro de 1930, o SPI foi incorporado ao Ministério do Trabalho, Indústria e Comércio.

- O Decreto $n^{\circ} 24.700$, de 12 de julho de 1934, transfere o SPI para a Inspetoria de Fronteiras do Ministério da Guerra. O Diário Oficial de 16 de julho do ano corrente, o artigo 129 da Constituição Brasileira de 1934 estabeleceu que "será respeitada a posse de terras de silvícolas que nelas se achem permanentemente localizados, sendo-lhes, no entanto, vedado aliená-las".

- O Decreto $\mathrm{n}^{\circ}$ 736, de 06 de abril de 1936, aprovou, provisoriamente, o Regulamento do SPI. O Decreto $n^{\circ}$ 911, de 18 de junho, subordinou o SPI diretamente ao Estado Maior do Exército.

- O Diário Oficial de 10 de novembro de 1937, publica o artigo 154 da Constituição Brasileira de 1937 declarando que "será respeitada aos silvícolas a posse das terras em que se achem localizados em caráter permanente, sendo-Ihes, porém, vedada a alienação das mesmas".

- O Decreto-Lei no 1.736 de 03 de novembro de 1939, subordina o SPI ao Ministério da Agricultura. O Decreto-Lei de 22 de novembro, cria o Conselho Nacional de Proteção aos Índios (CNPI) no Ministério da Agricultura. O Decreto-Lei $n^{\circ} 1.886$, de 15 de dezembro, organizou o SPI no Ministério da Agricultura.

- Em 16 de outubro de 1942, foi aprovado o regimento do SPI pelo Decreto $n^{\circ}$ 10.652. No dia 12 de novembro, por ato do Presidente da República, foi transferido o acervo da "Comissão Rondon" para o CNPI.

- Pelo Decreto $n^{\circ} 12.317$, de 27 de abril de 1943, foi aprovado o regimento do CNPI. O Decreto $\mathrm{n}^{\circ} 12.318$, promulgado no mesmo dia, modifica o Regimento do SPI. Pelo Decreto-Lei $n^{\circ} 5.540$, de 02 e junho de 1943, ficou estabelecida a data de 19 de abril como dia do índio.

- 1945. O Decreto-Lei no 17.684 , de 26 de janeiro, alterou o Regimento do SPI. 
- 1946. O D.O. de 19 de setembro, traz o artigo 216 da Constituição Brasileira de 1946, afirmando que "será respeitada aos silvícolas a posse das terras onde se achem permanentemente localizados com a condição de não a transferirem".

- 1951, o SPI elaborou substitutivo ao Projeto de Lei $n^{\circ} 250$, que circulava na Câmara dos Deputados, contendo proposta desfavorável aos índios relativa à medição e ao registro de propriedade das terras ocupadas pelos índios.

- 1953. O Decreto Legislativo $n^{\circ} 55$ filiou o Brasil ao Instituto Indigenista Interamericano (III).

- 1954. O Decreto $n^{\circ} 36.098$, de 19 de agosto promulgou a Convenção sobre o Instituto Indigenista Interamericano (III) definida no México há 14 anos (1940).

- 1956. A Lei $n^{\circ} 2.889$, de 01 de outubro, definiu e puniu o crime de genocídio - aquele que tem a intenção de destruir um grupo étnico.

- 1957. A Lei n 45.748 ordenava a distribuição anual de $3 \%$ da receita tributária às obras missionárias da Amazônia.

- Pelo Decreto $n^{\circ} 43.091$, de 22 de janeiro de 1958, o SPI passou a ser considerado de "interesse militar", podendo ser orientado por interesses de "segurança nacional".

- 1961. O Decreto $n^{\circ} 50.455$, de 14 de abril de 1961, criou o Parque Nacional do Xingu. O Decreto de criação foi regulamentado pelo Decreto $n^{\circ}$ 51.084, de 31 de julho de 1961.

- Em 03 de junho de 1962, o Diário do Congresso Nacional divulga que foi regulamentado o art. 216 da Constituição Federal que dava aos índios o direito de posse das terras que habitavam.

- O Decreto $n^{\circ}$ 52.668, de 11 de outubro de 1963, aprovou o novo regimento do $\mathrm{SPI}$. 
- O Decreto $n^{\circ} 58.824$, de 14 de julho de 1966, promulgou a Convenção $n^{\circ} 107$ da Organização Internacional do Trabalho sobre as populações indígenas e tribais.

- Em 05 de dezembro de 1967, é promulgada a Lei nº 5.371 autorizando a instituição da Fundação Nacional do Índio - FUNAI.

- O Decreto $\mathrm{n}^{\circ}$ 62.196, de 31 de janeiro de 1968, dispôs sobre os Estatutos da FUNAI (D.O. 01/2/1968). Em 16 de julho, o Decreto $n^{\circ} 62.998$ criou o Parque Nacional Indígena do Tumucumaque. No dia 06 de agosto, o Decreto $n^{\circ} 63.082$ alterou os limites da área do Parque Nacional do Xingu.

- O Decreto $n^{\circ} 64.860$, de 23 de julho de 1969, criou o Parque Indígena do Aripuanã. O D.O. de 20 de outubro, publica o artigo 186 da Constituição Brasileira de 1967 declarando que "é assegurada aos silvícolas a posse permanente das terras que habitam e reconhecido o seu direito ao usufruto exclusivo dos recursos naturais e de todas as utilidades nelas existentes". Também no mesmo Diário, é publicado o artigo 198 da Emenda Constitucional no 1, de 1969, determinando que "as terras habitadas pelos silvícolas são inalienáveis nos termos que a lei federal determinar, a eles cabendo a sua posse permanente e ficando reconhecido o seu direito ao usufruto exclusivo das riquezas naturais e de todas as utilidades nelas existentes. $\S$ $1^{\circ}$ - Ficam declaradas a nulidade e a extinção dos efeitos jurídicos de qualquer natureza que tenham por objeto o domínio, a posse ou a ocupação de terras habitadas pelos silvícolas; $\S 2^{\circ}-A$ nulidade $e$ a extinção de que trata o parágrafo anterior não dão aos ocupantes direito a qualquer ação ou indenização contra a União e a Fundação Nacional do Índio".

- O Decreto $n^{\circ}$ 68.909, de 13 de julho de 1971, alterou os limites do Parque Nacional do Xingu. No dia 22 de setembro, o Decreto $\mathrm{n}^{\circ}$ 69.263 criou o Parque Indígena do Araguaia. 
- Pela Portaria/GM/BSB n 1086, de 21 de julho de 1972, foi aprovado o Regimento Interno da FUNAI. O Decreto $n^{0} 71.258$, de 13 de outubro, instituiu a Medalha do Mérito Indigenista.

- No dia 19 de dezembro de 1973 , é promulgada a Lei $n^{\circ} 6.001$, que dispõe sobre o Estatuto do Índio.

- A Lei $n^{\circ}$ 6.938, de 31 de agosto de 1981, dispõe sobre a Política Nacional do Meio Ambiente.

- Em 1983, o Decreto n 88.118, de 23 de fevereiro, transferiu as decisões sobre demarcação de terras indígenas para um grupo de trabaIho integrado pela FUNAI/ Ministério do Interior/ Ministério Extraordinário para Assuntos Fundiários. No dia 10 de novembro, o Decreto ${ }^{\circ}$ 88.985 regulamentou os artigos $n^{\circ} 44$ e 45 do Estatuto do Índio (Lei $n^{\circ}$ 6.001), relativos à exploração mineral em terras indígenas.

- 1986, a Comissão Provisória de Estudos Constitucionais aprovou versão de texto Constitucional sobre Direitos Indígenas.

- É publicado o D.O. em 05 de outubro de 1988, sobre a Constituição Brasileira de 1988 dispondo de vários artigos sobre direitos indígenas e não somente os artigos 231 e 232, além do art. $67^{\circ}$ do Ato das Disposições constitucionais Provisórias: "A união concluirá a demarcação das terras indígenas no prazo de cinco anos a partir da promulgação da Constituição".

- 1990, o Decreto $n^{\circ}$ 98.812, de 09 de janeiro, proibiu a lavra garimpeira nas terras indígenas. No dia 15 de janeiro, o Decreto $n^{\circ} 98.830$ dispôs sobre a coleta de materiais científicos no Brasil por estrangeiros.

- 1991, a Lei $n^{\circ} 8.171$, de 17 de janeiro, colocou os indígenas como beneficiários do crédito rural. Em 04 de fevereiro, o Decreto $n^{\circ} 27$ conferiu à Comissão Especial instituída pelo Decreto $\mathrm{n}^{\circ} 99.971$ (03/1/1991) atribuições para propor a revisão do Estatuto do Índio. No dia 20 de março, a Portaria da FUNAI n 239 estabeleceu normas que regiam os trabalhos de identificação e delimitação de terras 
indígenas. A 16 de abril, a Portaria Interministerial n 559/MJ-MEC, criou no MEC a Coordenação Nacional de Educação Indígena e também garantiu aos índios o ensino bilíngüe (D.O. 17/4/1991). No dia 26 de abril, a Portaria $n^{\circ}$ 398/FUNAI instituiu comissão para reexame dos trabalhos de identificação e delimitação, e revisão das terras indígenas.

- 1992, o Decreto $n^{\circ}$ 564, de 08 de junho aprovou o Estatuto da FUNAI.

- 1993, a Portaria MJ n 542, de 21 de dezembro, aprovou o Regimento Interno da FUNAI.

- 1994, a revisão constitucional terminou sem alterar qualquer artigo constitucional a respeito dos direitos indígenas.

- Em 08 de janeiro de 1996, é promulgado o Decreto $n^{0} 1.775$, dispondo sobre o procedimento administrativo de demarcação de terras indígenas.

- O Decreto $n^{\circ} 3.108$, de 30 de junho de 1999, promulgou o Acordo que constituiu o Fundo para o Desenvolvimento dos Povos Indígenas da América Latina e do Caribe, estabelecido em Madri a 24 de julho de 1992. Em 08 de julho de 1999, a Resolução MS/CNS nº 293 aprovou a reestruturação do CISI - Comissão Intersetorial de Saúde do Índio. No dia 30 de setembro, a Portaria FUNASA nº 852 criou os Distritos Sanitários Especiais Indígenas. Em 10 de novembro, a Resolução CNE/CEB n ${ }^{\circ} 003$ fixou diretrizes nacionais para o funcionamento das escolas indígenas. Em 23 de novembro, a Lei $n^{\circ} 9.836$ acrescentou dispositivos à Lei $n^{\circ} 8.080$, de 19/09/1990, instituindo o Subsistema de Atenção à Saúde Indígena.

- Pelo Decreto n 3.551, de 04 de agosto de 2000, é instituído o registro de bens culturais de natureza imaterial, que faziam parte do patrimônio cultural brasileiro. Em 09 de agosto, a Resolução MS/CNS n 304 aprovou normas para pesquisas envolvendo povos indígenas. 


\section{ANEXO 2}

\section{MARCOS LEGAIS SOBRE OS DIREITOS FUNDAMENTAIS QUE INCIDE AOS POVOS INDÍGENAS RECONHECIDOS NA CONSTITUIÇÃO FEDERAL, PROMULGADA EM 05 DE OUTUBRO DE 1988:}

\section{1) Título I - Dos Princípios Fundamentais:}

Art. $1^{\circ} \mathrm{A}$ República Federativa do Brasil, formada pela união indissolúvel dos Estados e Municípios e do Distrito Federal, constitui-se em Estado democrático de direito e tem como fundamentos:

II - a cidadania;

III - a dignidade da pessoa humana;

$\mathrm{V}$ - o pluralismo político.

Parágrafo único. Todo o poder emana do povo, que o exerce por meio de representantes eleitos ou diretamente, nos termos desta Constituição. Art. $3^{\circ}$ Constituem objetivos fundamentais da República Federativa do Brasil:

I - construir uma sociedade livre, justa e solidária;

IV - promover o bem de todos, sem preconceitos de origem, raça, sexo, cor, idade e quaisquer outras formas de discriminação.

Art. $4^{\circ} \mathrm{A}$ República Federativa do Brasil rege-se nas suas relações internacionais pelos seguintes princípios:

II - prevalência dos direitos humanos;

III - autodeterminação dos povos;

VI - defesa da paz;

VII - solução pacífica dos conflitos; 
VIII - repúdio ao terrorismo e ao racismo ${ }^{45}$;

\section{Título II - Dos Direitos e Garantias Fundamentais}

\section{Capítulo I - Dos Direitos e Deveres Individuais e Coletivos.}

Art. $5^{\circ}$ Todos são iguais perante a lei, sem distinção de qualquer natureza, garantindo-se aos brasileiros e aos estrangeiros residentes no País a inviolabilidade do direito à vida, à liberdade, à igualdade, à segurança e à propriedade, nos termos seguintes:

III - ninguém será submetido a tortura nem a tratamento desumano ou degradante;

X - são invioláveis a intimidade, a vida privada, a honra e a imagem das pessoas, assegurado o direito a indenização pelo dano material ou moral decorrente de sua violação;

$X I$ - a casa é asilo inviolável do indivíduo, ninguém nela podendo penetrar sem consentimento do morador, salvo em caso de flagrante delito ou desastre, ou para prestar socorro, ou, durante o dia, por determinação judicial;

XXXIII - todos têm direito a receber dos órgãos públicos informações de seu interesse particular, ou de interesse coletivo ou geral, que serão prestadas no prazo da lei, sob pena de responsabilidade, ressalvadas aquelas cujo sigilo seja imprescindível à segurança da sociedade e do Estado;

XLI - a lei punirá qualquer discriminação atentatória dos direitos e liberdades fundamentais;

XLII - a prática do racismo constitui crime inafiançável e imprescritível, sujeito à pena de reclusão, nos termos da lei;

XLIII - a lei considerará crimes inafiançáveis e insuscetíveis de graça ou anistia a prática da tortura ${ }^{46}$, o tráfico ilícito de entorpecentes e drogas afins, o terrorismo e os definidos como crimes hediondos, por eles respondendo os mandantes, os executores e os que, podendo evitá-los, se omitirem;

45 Grifo meu.

46 Grifo meu. 
LXXVIII - a todos, no âmbito judicial e administrativo, são assegurados a razoável duração do processo e os meios que garantam a celeridade de sua tramitação.

$\S 1^{\circ}$ As normas definidoras dos direitos e garantias fundamentais têm aplicação imediata.

$\S 2^{\circ}$ Os direitos e garantias expressos nesta Constituição não excluem outros decorrentes do regime e dos princípios por ela adotados, ou dos tratados internacionais em que a República Federativa do Brasil seja parte.

$\S 3^{\circ}$ Os tratados e convenções internacionais sobre direitos humanos que forem aprovados, em cada Casa do Congresso Nacional, em dois turnos, por três quintos dos votos dos respectivos membros, serão equivalentes às emendas constitucionais.

$\S 4^{\circ} \mathrm{O}$ Brasil se submete à jurisdição de Tribunal Penal Internacional a cuja criação tenha manifestado adesão.

\section{Capítulo II - Dos Direitos Sociais}

(Alterado pela Emenda Constitucional $n^{\circ}$ 90, de 15 de setembro de 2015).

Art. $6^{\circ}$ São direitos sociais a educação, a saúde, a alimentação, o trabalho, a moradia, o transporte, o lazer, a segurança, a previdência social, a proteção à maternidade e à infância, a assistência aos desamparados, na forma desta Constituição.

\section{Título III - Da Organização do Estado}

\section{Capítulo II - Da União}

Art. 20. São bens da União:

$\mathrm{XI}$ - as terras tradicionalmente ocupadas pelos índios.

Art. 22. Compete privativamente à União legislar sobre:

XIV - populações indígenas;

Art. 23. É competência comum da União, dos Estados, do Distrito Federal e dos Municípios:

V - proporcionar os meios de acesso à cultura, à educação e à ciência; 
$\mathrm{VI}$ - proteger o meio ambiente e combater a poluição em qualquer de suas formas;

\section{Capítulo VII - Da Administração Pública}

\section{Seção I - Disposições Gerais}

Art. 37. A administração pública direta e indireta de qualquer dos Poderes da União, dos Estados, do Distrito Federal e dos Municípios obedecerá aos princípios de legalidade, impessoalidade, moralidade, publicidade e eficiência.

\section{Título IV - Da Organização dos Poderes}

\section{Seção II - Das Atribuições do Congresso Nacional}

Art. 48. Cabe ao Congresso Nacional, com a sanção do Presidente da República, não exigida esta para o especificado nos arts. 49, 51 e 52, dispor sobre todas as matérias de competência da União, especialmente sobre:

IV - planos e programas nacionais, regionais e setoriais de desenvolvimento;

$\mathrm{V}$ - limites do território nacional ${ }^{47}$, espaço aéreo e marítimo e bens do domínio da União ${ }^{48}$;

Art. 49. É da competência exclusiva do Congresso Nacional:

I - resolver definitivamente sobre tratados, acordos ou atos internacionais que acarretem encargos ou compromissos gravosos ao patrimônio nacional;

$\mathrm{XVI}$ - autorizar, em terras indígenas, a exploração e o aproveitamento de recursos hídricos e a pesquisa e lavra de riquezas minerais;

\section{Seção V - Dos Deputados e dos Senadores}

Art. 53. (Alterado pela Emenda Constitucional $n^{\circ}$ 35, de 20 de dezembro de 2001): Os Deputados e Senadores são invioláveis, civil e penalmente, por quaisquer de suas opiniões, palavras e votos.

47 Grifo meu.

48 Grifo meu. 


\section{Subseção II - Da Emenda à Constituição}

Art. 60. A Constituição poderá ser emendada mediante proposta.

$\S 4^{\circ}$ Não será objeto de deliberação a proposta de emenda tendente a abolir:

IV - os direitos e garantias individuais.

\section{Seção III - Da Responsabilidade do Presidente da República}

Art. 85. São crimes de responsabilidade os atos do Presidente da República que atentem contra a Constituição Federal e, especialmente, contra:

III - o exercício dos direitos políticos, individuais e sociais;

\section{Seção IV - Dos Tribunais Regionais Federais e dos Juízes Federais}

Art. 109. Aos juizes federais compete processar e julgar:

V-A. (Acrescido pela Emenda Constitucional $n^{\circ} 45$, de 08 de dezembro de 2004): as causas relativas a direitos humanos a que se refere o $\S$ $5^{\circ}$ deste artigo;

$\mathrm{XI}$ - a disputa sobre direitos indígenas.

$\S 5^{\circ}$ (Acrescido pela Emenda Constitucional $n^{\circ} 45$, de 08 de dezembro de 2004): Nas hipóteses de grave violação de direitos humanos, o Procurador-Geral da República, com a finalidade de assegurar o cumprimento de obrigações decorrentes de tratados internacionais de direitos humanos dos quais o Brasil seja parte, poderá suscitar, perante o Superior Tribunal de Justiça, em qualquer fase do inquérito ou processo, incidente de deslocamento de competência para a Justiça Federal.

\section{Capítulo IV - Das funções Essenciais à Justiça}

\section{Seção I - Do Ministério Público}

Art. 129 São funções institucionais do Ministério Público:

III - promover o inquérito civil e a ação pública, para a proteção do patrimônio público e social, do meio ambiente e de outros interesses difusos e coletivos;

$\checkmark$ - defender judicialmente os direitos e interesses das populações indígenas. 


\section{Título VII - Da Ordem Econômica e Financeira}

\section{Capítulo I - Dos Princípios Gerais da Atividade Econômica}

Art. 170. A ordem econômica, fundada na valorização do trabalho humano e na livre iniciativa, tem por fim assegurar a todos existência digna, conforme os ditames da justiça social, observados os seguintes princípios:

$\mathrm{VI}$ - defesa do meio ambiente, inclusive mediante tratamento diferenciado conforme o impacto ambiental dos produtos e serviços e de seus processos de elaboração e prestação;

VII - redução das desigualdades regionais e sociais;

IX - tratamento favorecido para as empresas de pequeno porte constituídas sob as leis brasileiras e que tenham sua sede e administração no País.

Art. 176. As jazidas, em lavra ou não, e demais recursos minerais e os potenciais de energia hidráulica constituem propriedade distinta da do solo, para efeito de exploração ou aproveitamento, e pertencem à União, garantida ao concessionário a propriedade do produto da lavra. $\S 1^{\circ} \mathrm{A}$ pesquisa e a lavra de recursos minerais e o aproveitamento dos potenciais a que se refere o caput deste artigo somente poderão ser efetuados mediante autorização ou concessão da União, no interesse nacional, por brasileiros ou empresa constituída sob as leis brasileiras e que tenha sua sede e administração no País, na forma da lei, que estabelecerá as condições específicas quando essas atividades se desenvolverem em faixa de fronteira ou terras indígenas.

\section{Capítulo III - Da Educação, da Cultura e do Desporto}

\section{Seção I - Da Educação}

Art. 205. A educação, direito de todos e dever do Estado e da família, será promovida e incentivada com a colaboração da sociedade, visando ao pleno desenvolvimento da pessoa, seu preparo para o exercício da cidadania e sua qualificação para o trabalho. 
Art. 210 Serão fixados conteúdos para o ensino fundamental, de maneira a assegurar formação básica comum e respeito aos valores culturais e artísticos, nacionais e regionais.

$\S 2^{\circ} \mathrm{O}$ ensino fundamental regular será ministrado em língua portuguesa, assegurada às comunidades indígenas também a utilização de suas línguas maternas e processos próprios de aprendizagem.

\section{Seção II - Da Cultura}

Art. 215. (Incluído o $\S 3^{\circ}$ pela Emenda Constitucional $n^{\circ} 48$, de 10 de agosto de 2005): O Estado garantirá a todos o pleno exercício dos direitos culturais e acesso às fontes da cultura nacional, e apoiará e incentivará a valorização e a difusão das manifestações culturais.

$\S 1^{\circ} \mathrm{O}$ Estado protegerá as manifestações das culturas populares, indígenas e afro-brasileiras, e das de outros grupos participantes do processo civilizatório nacional.

$\S 2^{\circ}$ A lei disporá sobre a fixação de datas comemorativas de alta significação para os diferentes segmentos étnicos nacionais.

$\S 3^{\circ}$ A lei estabelecerá o Plano Nacional de Cultura, de duração plurianual, visando ao desenvolvimento cultural do País e à integração das ações do poder público que conduzem à:

I - defesa e valorização do patrimônio cultural brasileiro;

II - produção, promoção e difusão de bens culturais;

III - formação de pessoal qualificado para a gestão da cultura em suas múltiplas dimensões;

IV - democratização do acesso aos bens de cultura;

V - valorização da diversidade étnica e regional.

Art. 216. Constituem patrimônio cultural brasileiro os bens de natureza material e imaterial, tomados individualmente ou em conjunto, portadores de referência à identidade, à ação, à memória dos diferentes grupos formadores da sociedade brasileira, nos quais se incluem:

I - as formas de expressão;

II - os modos de criar, fazer e viver; 
$\S 4^{\circ}$ Os danos e ameaças ao patrimônio cultural serão punidos, na forma da lei.

Art. 216-A. (Incluído pela Emenda Constitucional n 71 , de 29 de novembro de 2012): O Sistema Nacional de Cultura, organizado em regime de colaboração, de forma descentralizada e participativa, institui um processo de gestão e promoção conjunta de políticas públicas de cultura, democráticas e permanentes, pactuadas entre os entes da Federação e a sociedade, tendo por objetivo promover o desenvolvimento humano, social e econômico com pleno exercício dos direitos culturais.

$\S 1^{\circ} \mathrm{O}$ Sistema Nacional de Cultura fundamenta-se na política nacional de cultura e nas suas diretrizes, estabelecidas no Plano Nacional de Cultura, e rege-se pelos seguintes princípios:

I - diversidade das expressões culturais;

\section{Capítulo VI - Do Meio Ambiente}

Art. 225. Todos têm direito ao meio ambiente ecologicamente equilibrado, bem de uso comum do povo e essencial à sadia qualidade de vida, impondo-se ao poder público e à coletividade o dever de defendê-lo e preservá-lo para as presentes e futuras gerações.

$\S 1^{\circ}$ Para assegurar a efetividade desse direito, incumbe ao poder público:

I - preservar e restaurar os processos ecológicos essenciais e prover o manejo ecológico das espécies e ecossistemas;

II - preservar a diversidade e a integridade do patrimônio genético do País e fiscalizar as entidades dedicadas à pesquisa e manipulação de material genético;

III - definir, em todas as unidades da Federação, espaços territoriais e seus componentes a serem especialmente protegidos, sendo a alteração e a supressão permitidas somente através de lei, vedada qualquer utilização que comprometa a integridade dos atributos que justifiquem sua proteção;

IV - exigir, na forma da lei, para instalação de obra ou atividade potencialmente causadora de significativa degradação do meio ambiente, estudo prévio de impacto ambiental, a que se dará publicidade; 
V - controlar a produção, a comercialização e o emprego de técnicas, métodos e substâncias que comportem risco para a vida, a qualidade de vida e o meio ambiente;

VI - promover a educação ambiental em todos os níveis de ensino e a conscientização pública para a preservação do meio ambiente;

VII - proteger a fauna e a flora, vedadas, na forma da lei, as práticas que coloquem em risco sua função ecológica, provoquem a extinção de espécies ou submetam os animais a crueldade.

$\S 2^{\circ}$ Aquele que explorar recursos minerais fica obrigado a recuperar o meio ambiente degradado, de acordo com solução técnica exigida pelo órgão público competente, na forma da lei.

$\S 3^{\circ}$ As condutas e atividades consideradas lesivas ao meio ambiente sujeitarão os infratores, pessoas físicas ou jurídicas, a sanções penais e administrativas, independentemente da obrigação de reparar os danos causados.

§ $4^{\circ}$ A Floresta Amazônica brasileira, a Mata Atlântica, a Serra do Mar, o Pantanal Mato-Grossense e a Zona Costeira são patrimônio nacional, e sua utilização far-se-á, na forma da lei, dentro de condições que assegurem a preservação do meio ambiente, inclusive quanto ao uso dos recursos naturais.

$\S 5^{\circ}$ São indisponíveis as terras devolutas ou arrecadadas pelos Estados, por ações discriminatórias, necessárias à proteção dos ecossistemas naturais.

$\S 6^{\circ}$ As usinas que operem com reator nuclear deverão ter sua localização definida em lei federal, sem o que não poderão ser instaladas.

\section{Capítulo VII - Da Família, da Criança, do Adolescente, do Jovem e do Idoso}

(Alterado pela Emenda Constitucional $n^{\circ}$ 65, de 13 de junho de 2010).

Art. 227. É dever da família, da sociedade e do Estado assegurar à criança, ao adolescente e ao jovem, com absoluta prioridade, o direito à vida, à saúde, à alimentação, à educação, ao lazer, à profissionalização, à cultura, à dignidade, ao respeito, à liberdade e à convivência 
familiar e comunitária, além de colocá-los a salvo de toda forma de negligência, discriminação, exploração, violência, crueldade e opressão. Art. 230. A família, a sociedade e o Estado têm o dever de amparar as pessoas idosas, assegurando sua participação na comunidade, defendendo sua dignidade e bem-estar e garantindo-Ihes o direito à vida.

\section{Capítulo VIII - Dos Índios}

Art. 231. São reconhecidos aos índios sua organização social, costumes, línguas, crenças e tradições, e os direitos originários sobre as terras que tradicionalmente ocupam, competindo à União demarcá-las, proteger e fazer respeitar todos os seus bens.

$\S 1^{\circ}$ São terras tradicionalmente ocupadas pelos índios as por eles habitadas em caráter permanente, as utilizadas para suas atividades produtivas, as imprescindíveis à preservação dos recursos ambientais necessários a seu bem-estar e as necessárias a sua reprodução física e cultural, segundo seus usos, costumes e tradições.

$\S 2^{\circ}$ As terras tradicionalmente ocupadas pelos índios destinam-se a sua posse permanente, cabendo-lhes o usufruto exclusivo das riquezas do solo, dos rios e dos lagos nelas existentes.

$\S 3^{\circ} \mathrm{O}$ aproveitamento dos recursos hídricos, incluídos os potenciais energéticos, a pesquisa e a lavra das riquezas minerais em terras indígenas só podem ser efetivados com autorização do Congresso Nacional, ouvidas as comunidades afetadas, ficando-lhes assegurada participação nos resultados da lavra, na forma da lei.

$\S 4^{\circ}$ As terras de que trata este artigo são inalienáveis e indisponíveis, e os direitos sobre elas, imprescritíveis.

$\S 5^{\circ}$ É vedada a remoção dos grupos indígenas de suas terras, salvo, ad referendum do Congresso Nacional, em caso de catástrofe ou epidemia que ponha em risco sua população, ou no interesse da soberania do País, após deliberação do Congresso Nacional, garantido, em qualquer hipótese, o retorno imediato logo que cesse o risco.

$\S 6^{\circ}$ São nulos e extintos, não produzindo efeitos jurídicos, os atos que tenham por objeto a ocupação, o domínio e a posse das terras a que se refere este artigo, ou a exploração das riquezas naturais do solo, 
dos rios e dos lagos nelas existentes, ressalvado relevante interesse público da União, segundo o que dispuser lei complementar, não gerando a nulidade e a extinção direito a indenização ou a ações contra a União, salvo, na forma da lei, quanto às benfeitorias derivadas da ocupação de boa-fé.

$\S 7^{\circ}$ Não se aplica às terras indígenas o disposto no art. 174 , $\S \S 3^{\circ}$ e $4^{\circ}$. Art. 232. Os índios, suas comunidades e organizações são partes legítimas para ingressar em juízo em defesa de seus direitos e interesses, intervindo o Ministério Público em todos os atos do processo.

\section{Título IX - Das Disposições Constitucionais Gerais}

Art. 242. O princípio do art. 206, IV, não se aplica às instituições educacionais oficiais criadas por lei estadual ou municipal e existentes na data da promulgação desta Constituição, que não sejam total ou preponderantemente mantidas com recursos públicos.

$\S 1^{\circ} \mathrm{O}$ ensino da História do Brasil levará em conta as contribuições das diferentes culturas e etnias para a formação do povo brasileiro.

\section{ANEXO 3}

\section{LISTA POR ORDEM CRONOLÓGICA SOBRE INSTRUMENTOS INTERNACIONAIS RATIFICADOS PELO BRASIL QUE INCIDEM SOBRE A QUESTÃO INDÍGENA:}

1. 1919: Pacto da Sociedade das Nações.

2. 1944: Constituição da Organização Internacional do Trabalho (OIT) e seu Anexo - Declaração de Filadélfia.

3. 1945: Carta das Nações Unidas.

4. 1948: Carta das Organizações dos Estados Americanos (1951). 
5. 1948: Convenção para Prevenção e Repressão do crime de Genocídio.

6. 1948: Declaração Universal dos Direitos Humanos.

7. 1965: Convenção Internacional sobre Eliminação de todas as formas de Discriminação Racial.

8. 1966: Pacto Internacional dos Direitos Econômicos, Sociais e Culturais.

9. 1966: Pacto internacional sobre Direitos Civis e Políticos.

10. 1966: Protocolo Facultativo relativo ao Pacto Internacional sobre Direitos Civis e Políticos.

11. 1969: Convenção Americana sobre Direitos Humanos - Pacto de San José da Costa Rica.

12. 1969: Convenção de Viena sobre o Direito dos Tratados.

13. 1975: Declaração sobre a Proteção de todas as Pessoas contra a Tortura ou outros Tratamentos ou Penas Cruéis, Desumanos ou Degradantes.

14. 1979: Convenção Internacional sobre Eliminação de todas as formas de Discriminação contra a Mulher.

15. 1984: Convenção Internacional contra a Tortura e outros Tratamentos ou Penas Cruéis, Desumanos ou Degradantes.

16. 1986: Convenção de Viena sobre o Direito de Tratados entre Estados e Organizações Internacionais ou entre Organizações Internacionais.

17. 1986: Declaração sobre o Direito ao Desenvolvimento. 
18. 1988: Protocolo Adicional à Convenção Americana sobre Direitos Humanos em matéria de Direitos Econômicos, Sociais e Culturais - Protocolo de San Salvador.

19. 1989: Convenção 169 da Organização Internacional do Trabalho (OIT) sobre Povos Indígenas e Tribais.

20. 1989: Convenção sobre os Direitos da Criança.

21. 1989: Segundo Protocolo Adicional ao Pacto Internacional sobre os Direitos Civis e Políticos com vistas à abolição da Pena de Morte.

22. 1992: Declaração do Rio de Janeiro sobre Meio Ambiente.

23. 1992: Convenção da Diversidade Biológica.

24. 1992: Convenção-Quadro das Nações Unidas sobre Mudanças do Clima.

25. 1992: Convenção Internacional para a Proteção de todas as Pessoas contra os Desaparecimentos Forçados.

26. 1993: Declaração e Programa de Ação de Viena.

27. 1993: Declaração Universal dos Povos Indígenas.

28. 1994: Convenção Interamericana para prevenir, punir e erradicar a violência contra a Mulher - Convenção de Belém do Pará.

29. 1995: Declaração de Pequim adotada pela Quarta Conferência sobre as mulheres - ação para igualdade, desenvolvimento e paz.

30. 1997: Protocolo de Quioto à Convenção-Quadro das Nações Unidas sobre Mudanças do Clima.

31. 1999: Protocolo Facultativo à Convenção Internacional sobre Eliminação de todas as formas de Discriminação contra a Mulher. 
32. 2001: Tratado Internacional sobre Recursos Fitogenéticos para a Alimentação e Agricultura.

33. 2005: Convenção sobre a proteção e promoção da Diversidade das Expressões Culturais.

34. 2007: Declaração das Nações Unidas sobre os Direitos dos Povos Indígenas.

\section{ANEXO 4}

\section{LISTA POR ORDEM CRONOLÓGICA SOBRE LEGISLAÇÃO AMBIENTAL}

1605: Surge a primeira lei de cunho ambiental no País: o Regimento do Pau-Brasil, voltado à proteção das florestas.

1797: Carta régia afirma a necessidade de proteção a rios, nascentes e encostas, que passam a ser declarados propriedades da Coroa.

1799: É criado o Regimento de Cortes de Madeiras, cujo teor estabelece rigorosas regras para a derrubada de árvores.

1850: É promulgada a Lei $n^{\circ}$ 601/1850 em 18 de setembro de 1850, a primeira Lei de Terras do Brasil. Ela disciplina a ocupação do solo e estabelece sanções para atividades predatórias.

1911: É expedido o Decreto $n^{\circ} 8.843$, de 26 de julho de 1911, que cria a primeira reserva florestal do Brasil, no antigo Território do Acre.

1916: Surge o Código Civil Brasileiro, que elenca várias disposições de natureza ecológica. A maioria, no entanto, reflete uma visão patrimonial, de cunho individualista.

1934: São sancionados o Código Florestal, que impõe limites ao exercício do direito de propriedade, e o Código das Águas. Eles contêm o embrião do que viria a constituir, décadas depois, a atual legislação ambiental brasileira. 
1964: Em 30 de novembro de 1964, é promulgada a Lei $n^{\circ} 4.504$, que trata do Estatuto da Terra. A lei surge como resposta a reivindicações de movimentos sociais, que exigiam mudanças estruturais na propriedade e no uso da terra no Brasil.

1965: Lei $n^{\circ} 4.771$, de 15 de setembro de 1965. Institui o Código Florestal. Revogada pela Lei $n^{\circ} 12.651$, de 25 de maio de 2012.

1965: Passa a vigorar uma nova versão do Código Florestal, ampliando políticas de proteção e conservação da flora. Inovador, estabelece a proteção das áreas de preservação permanente.

1967: São editados os Códigos de Caça, de Pesca e de Mineração, bem como a Lei de Proteção a Fauna. Uma nova Constituição atribui à União competência para legislar sobre jazidas, florestas, caça, pesca e águas, cabendo aos Estados tratar de matéria florestal.

1975: Inicia-se o controle da poluição provocada por atividades industriais. Por meio do Decreto-Lei $n^{\circ} 1.413$, de 14 de agosto de 1975, empresas poluidoras ficam obrigadas a prevenir e corrigir os prejuízos da contaminação do meio ambiente.

1977: É promulgada a Lei $n^{\circ} 6.453$, em 17 de outubro de 1977, que estabelece a responsabilidade civil em casos de danos provenientes de atividades nucleares.

1981: É editada a Lei no 6.938, em 31 de agosto de 1981, que dispõe sobre a Política Nacional do Meio Ambiente, seus fins e mecanismos de formulação e aplicação, e dá outras providências. A lei inova ao apresentar o meio ambiente como objeto específico de proteção.

1985: Lei $n^{\circ} 7.347$, de 24 de julho de 1985. Disciplina a ação civil pública de responsabilidade por danos causados ao meio ambiente, ao consumidor, a bens e direitos de valor artístico, estético, histórico, turístico e paisagístico e dá outras providências.

1986: Resolução/CONAMA no 1, de 23 de janeiro de 1986. Dispõe sobre critérios básicos e diretrizes gerais para a avaliação de impacto ambiental. Alterada pela Resolução $n^{0} 11 / 86$ (alterado o art. $2^{\circ}$ ). Alterada pela Resolução no 5/87 (acrescentado o inciso XVIII). Alterada pela Resolução $n^{\circ} 237 / 97$ (revogados os art. $3^{\circ}$ e $7^{\circ}$ ). 
1988: É promulgada a Constituição Federal, em 05 de outubro, a primeira a dedicar um capítulo específico ao meio ambiente. Avançada, impõe ao Poder Público e à coletividade, em seu art. 225, o dever de defender e preservar o meio ambiente para as gerações presentes e futuras.

1991: O Brasil passa a dispor da Lei de Política Agrícola (Lei $n^{\circ} 8.171$, de 17 de janeiro de 1991). Com um capítulo especialmente dedicado à proteção ambiental, o texto obriga o proprietário rural a recompor sua propriedade com reserva florestal obrigatória.

1994: Decreto $n^{\circ} 1.141$, de 19 de maio de 1994. Dispõe sobre as ações de proteção ambiental, saúde e apoio as atividades produtivas para as comunidades indígenas. Revogado pelo Decreto 7.7.47/2012.

1995: Lei n 9.008, de 21 de março de 1995. Cria, na estrutura organizacional do Ministério da Justiça, o Conselho Federal de que trata o art. 13 da Lei $n^{\circ} 7.347$, de 24 de julho de 1985, altera os arts. $4^{\circ}, 39,82,91$ e 98 da Lei ${ }^{\circ} 8.078$, de 11 de setembro de 1990, e dá outras providências.

1997: Resolução/CONAMA n 237, de 19 de dezembro de 1997. Dispõe sobre a revisão e complementação dos procedimentos e critérios utilizados para o licenciamento ambiental.

1998: É publicada a Lei $n^{\circ}$ 9.605, em 12 de fevereiro de 1998, que dispõe sobre crimes ambientais. A lei prevê sanções penais e administrativas para condutas e atividades lesivas ao meio ambiente.

1999: Decreto $n^{\circ} 3.156$, de 27 de agosto de 1999. Dispõe sobre as condições para a prestação de assistência à saúde dos povos indígenas, no âmbito do Sistema Único de Saúde, pelo Ministério da Saúde, altera dispositivos dos Decretos $\mathrm{n}^{\circ} \mathrm{s} 564$, de 8 de junho de 1992, e 1.141 , de 19 de maio de 1994, e dá outras providências.

1999: Lei $n^{\circ}$ 9.795, de 27 de abril de 1999. Dispõe sobre a educação ambiental, institui a Política Nacional de Educação Ambiental e dá outras providências.

2000: Surge a Lei $n^{\circ} 9.985$, de 18 de julho de 2000), que regulamenta o art. 225, $\S 1^{\circ}$, incisos I, II, III e VII da Constituição Federal, institui o Sistema Nacional de Unidades de Conservação da Natureza e dá ou- 
tras providências. Prevê mecanismos para a defesa dos ecossistemas naturais e de preservação dos recursos naturais neles contidos.

2001: Decreto $n^{\circ} 3.799$, de 19 de abril de 2001. Altera dispositivos do Decreto no 1.141, de 19 de maio de 1994, que dispõe sobre as ações de proteção ambiental, saúde e apoio às atividades produtivas para as comunidades indígenas. Revogado pelo Decreto $n^{0} 7.747 / 2012$.

2001: É sancionado o Estatuto das Cidades (Lei $n^{\circ}$ 10.257, de 10 de julho de 2001), que regulamenta os arts. 182 e 183 da Constituição Federal/88, estabelece diretrizes gerais da política urbana e dá outras providências, dota o ente municipal de mecanismos visando permitir que seu desenvolvimento não ocorra em detrimento do meio ambiente.

2001: Medida Provisória n².163-41, de 23 de agosto de 2001. Acrescenta dispositivos à Lei $n^{\circ}$ 9.605, de 12 de fevereiro de 1998, que dispõe sobre as sanções penais e administrativas derivadas de conduta e atividades lesivas ao meio ambiente.

2001: Medida Provisória $n^{\circ} 2.186-16$, de 23 de agosto de 2001. Regulamenta o inciso II do $\S 1^{\circ}$ e o $\S 4^{\circ}$ do art. 225 da Constituição, os arts. $1^{\circ}, 8^{\circ}$, alínea "j", 10, alínea "c", 15 e 16, alíneas 3 e 4 da Convenção sobre Diversidade Biológica, dispõe sobre o acesso ao patrimônio genético, a proteção e o acesso ao conhecimento tradicional associado, a repartição de benefícios e o acesso à tecnologia e transferência de tecnologia para sua conservação e utilização, e dá outras providências. Revogado pela Lei 13.123/2015.

2002: Decreto $n^{\circ} 4.519$, de 13 de dezembro de 2001. Dispõe sobre o serviço voluntário em unidades de conservação federais, e dá outras providências.

2006: Lei $n^{0} 11.284$, de 02 de março de 2006. Dispõe sobre a gestão de florestas públicas para a produção sustentável; institui, na estrutura do Ministério do Meio Ambiente, o Serviço Florestal Brasileiro (SFB); cria o Fundo Nacional de Desenvolvimento Florestal (FNDF); altera as Leis $\mathrm{n}^{\circ} \mathrm{s} 10.683$, de 28 de maio de 2003, 5.868, de 12 de dezembro de 1972, 9.605, de 12 de fevereiro de 1998, 4.771, de 15 de setembro de 1965, 6.938, de 31 de agosto de 1981, e 6.015, de 31 de dezembro de 1973; e dá outras providências. 
2006: Resolução/CONAMA n 378, de 19 de outubro de 2006. Define os empreendimentos potencialmente causadores de impacto ambiental nacional ou regional para fins do disposto no inciso III, $\S 1^{\circ}$, art. 19 da Lei $n^{\circ} 4.771$, de 15 de setembro de 1965 e dá outras providências. Alterada pela Resolução/CONAMA n 428/2010.

2007: Resolução/MMA/CGEN n² 29, de 06 de dezembro de 2007. Dispõe sobre o enquadramento de óleos fixos, óleos essenciais e extratos no âmbito da Medida Provisória n².186-16, de 23 de agosto de 2001.

2008: Decreto $n^{\circ} 6.514$, de 22 de julho de 2008. Dispõe sobre as infrações e sanções administrativas ao meio ambiente, estabelece o processo administrativo federal para apuração destas infrações, e dá outras providências.

2010: Resolução/CONAMA n 428, de 17 de dezembro de 2010. Dispõe, no âmbito do licenciamento ambiental, sobre a autorização do órgão responsável pela administração da Unidade de Conservação (UC), de que trata o artigo $36, \S 3^{\circ}$, da Lei $n^{\circ} 9.985$, de 18 de julho de 2000, bem como sobre a ciência do órgão responsável pela administração da UC no caso de licenciamento ambiental de empreendimentos não sujeitos a EIA-RIMA e dá outras providências.

2011: Lei Complementar $n^{\circ} 140$, de 08 de dezembro de 2011. Fixa normas, nos termos dos incisos III, VI e VII do caput e do parágrafo único do art. 23 da Constituição Federal, para a cooperação entre a União, os Estados, o Distrito Federal e os Municípios nas ações administrativas decorrentes do exercício da competência comum relativas à proteção das paisagens naturais notáveis, à proteção do meio ambiente, ao combate à poluição em qualquer de suas formas e à preservação das florestas, da fauna e da flora; e altera a Lei $n^{\circ}$ 6.938, de 31 de agosto de 1981.

2011: Resolução/MMA n 35, de 27 de abril de 2011. Dispõe sobre a regularização de atividades de acesso ao patrimônio genético e/ou ao conhecimento tradicional associado e sua exploração econômica realizadas em desacordo com a Medida Provisória $n^{\circ} 2.186-16$, de 23 de agosto de 2001 e demais normas pertinentes. 
2012: A Instrução Normativa/IBAMA $n^{\circ}$ 2, de 27 de março de 2012, estabelece as bases técnicas para programas de educação ambiental apresentados como medidas mitigadoras ou compensatórias, em cumprimento às condicionantes das licenças ambientais emitidas pelo Instituto Brasileiro do Meio Ambiente e dos Recursos Naturais Renováveis (IBAMA).

2012: Decreto $n^{\circ} 7.7 .47$, de 05 de junho de 2012. Institui a Política Nacional de Gestão Territorial e Ambiental de Terras Indígenas - PNGATI, e dá outras providências.

2012: Instrução Normativa/IBAMA n 10, de 07 de dezembro de 2012. Regula os procedimentos para apuração de infrações administrativas por conduta e atividades lesivas ao meio ambiente, a imposição das sanções, a defesa, o sistema recursal e a cobrança de multas no âmbito do Instituto Brasileiro do Meio Ambiente e dos Recursos Naturais Renováveis (IBAMA).

2012: Lei no 12.651, de 25 de maio de 2012. Dispõe sobre a proteção da vegetação nativa; altera as Leis $n^{\circ}$ s 6.938, de 31 de agosto de 1981, 9.393, de 19 de dezembro de 1996, e 11.428, de 22 de dezembro de 2006; revoga as Leis n`s 4.771, de 15 de setembro de 1965, e 7.754, de 14 de abril de 1989, e a Medida Provisória n².166-67, de 24 de agosto de 2001; e dá outras providências. Institui o novo Código Florestal.

2012: Orientação Jurídica Normativa/IBAMA n 40/2012. Configuração de infração ambiental em razão de construção de casas de moradia em Área de Proteção Ambiental (APA).

2013: Instrução Normativa/IBAMA no 15, de 19 de julho de 2013. Altera os arts. 12, 126 e o Anexo I da IN/IBAMA n 10, de 07 de dezembro de 2012.

2013: Resolução/MMA n 40, de 27 de fevereiro de 2013. Dispõe sobre a repartição de benefícios nas hipóteses que especifica.

2014: Lei $n^{\circ} 13.004$, de 24 de junho de 2014 . Altera os arts. $1^{\circ}, 4^{\circ}$ e $5^{\circ}$ da Lei $n^{\circ} 7.347$, de 24 de julho de 1985, para incluir, entre as finalidades de ação civil pública, a proteção do patrimônio público e social. 
2015: Lei 13.123, de 20 de maio de 2015. Dispõe sobre o acesso ao patrimônio genético, sobre a proteção e o acesso ao conhecimento tradicional associado e sobre a repartição de benefícios para conservação e uso sustentável da biodiversidade.

2016: Decreto $n^{\circ} 8.772$, de 11 de maio de 2016. Regulamenta a Lei 13.123, de 20 de maio de 2015, que dispõe sobre o acesso ao patrimônio genético, sobre a proteção e o acesso ao conhecimento tradicional associado e sobre a repartição de benefícios para conservação e uso sustentável da biodiversidade. 